\author{
Universidade de São Paulo \\ Faculdade de Filosofia, Letras e Ciências Humanas \\ Departamento de Ciência Política
}

Rafael Nunes Magalhães

\title{
A Economia Política da Ajuda Externa
}

Versão corrigida

São Paulo

2018 
Autorizo a reprodução e divulgação total ou parcial deste trabalho, por qualquer meio convencional ou eletrônico, para fins de estudo e pesquisa, desde que citada a fonte.

Catalogação na Publicação

Serviço de Biblioteca e Documentação

Faculdade de Filosofia, Letras e Ciências Humanas da Universidade de São Paulo

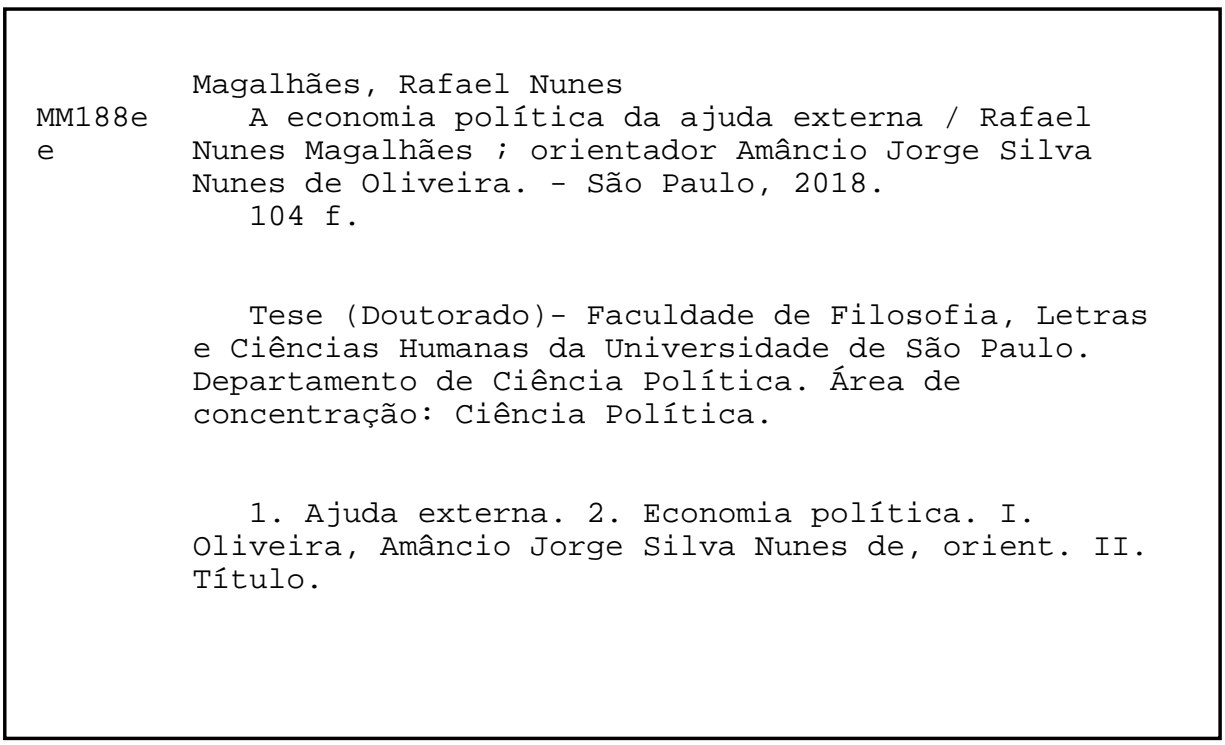




\section{Agradecimentos}

Durante a pós-graduação, tive o privilégio de contar com o apoio de algumas das pessoas mais generosas com quem já tive a oportunidade de trabalhar. Aos professores Amâncio de Oliveira e Janina Onuki, agradeço pela orientação em todo o período da pós, pela confiança e pela liberdade de trabalho. A abertura de ambos para a interlocução e sua disposição de ajudar foram determinantes para a superação dos momentos mais difíceis deste processo. Ter sido acolhido no Caeni foi, de longe, o fator mais importante da minha formação.

Agradeço especialmente a Flávio Pinheiro pela amizade, pelas conversas madrugada adentro e pelas constantes referências do Seinfeld. Agradeço também a Gabriel Cepaluni, Ivan Fernandes e Gustavo Araújo pelas discussões dentro e fora do âmbito do GEP. A Rodrigo Nakahara, que está entre as pessoas mais competentes e caprichadas que já conheci. Aos amigos do Caeni e do DCP, que menciono já sabendo que vou esquecer de incluir muita gente: Sérgio Simoni, Fábio Lacerda, Rodrigo Martins, Maurício Izumi, Matheus Hardt, Gabriela Ferreira, Murilo Zacareli, Francisco Urdinez, Fernando Morón, Raíssa Ventura, Lucas Petroni, Marcos Paulo de Lucca. Por fim, agradeço aos amigos do grupo Sem Dúvida, mas Duvido: Umberto Mignozzetti, por me ensinar pacientemente as primeiras lições de metodologia; Manoel Galdino, que se mantém sempre curioso e é constante fonte de inspiração; Davi Moreira, pelas conversas e pelos litros de café, cachaça e cerveja; e Lincon Ribeiro, pela dedicação com que sempre bota lenha na fogueira.

Agradeço ao DCP pelo apoio institucional e pelo ambiente acadêmico. Muito obrigado aos funcionários, que sempre estiveram à disposição para desatar os nós burocráticos da universidade, e aos professores que, pelo exemplo e pela dedicação, estimulam a vocação para a pesquisa.

Por fim, e mais importante, agradeço o carinho e apoio da minha família. Agradeço especialmente minha mãe, a quem dedico esta tese. 


\section{Resumo}

Esta tese consiste em três estudos que investigam os impactos políticos do investimento em ajuda externa, assim como as estratégias de alocação interna por parte dos líderes dos países receptores. Explorando diferentes níveis de análise e conjuntos de países, eles buscam contribuir com o entendimento de escolhas estratégicas feitas por parte dos países doadores e por parte dos países recipientes.

O capítulo 1 explora como líderes locais utilizam recursos de ajuda externa para se perpetuar no poder. Os resultados mostram que, em eleições competitivas, líderes direcionam recursos com o objetivo de ampliar sua base para além dos core voters. Quando as eleições não são competitivas, os líderes têm menos motivos para duvidar de sua sobrevivência eleitoral e direcionam recursos para distritos de sua etnia. A disponibilidade de informações sobre ajuda externa em nível sub-nacional é rara, e esse estudo toma proveito da liberação de novas bases de dados que sistematizam os investimentos chineses na África.

O capítulo 2 adota um nível de análise mais tradicional nos estudos de ajuda externa. Utilizando-se dados de 155 países entre 1960 e 2011, ele investiga se o investimento em ajuda externa tem efeitos heterogêneos em países com regimes democráticos e autoritários. Os resultados demonstram que países democráticos alocam ajuda de maneira mais efetiva do que países autoritários, mas as estimativas apresentam volatilidade.

O capítulo 3 investiga o possível impacto da ajuda externa sobre a intensidade de conflitos civis. Em países com menor grau de institucionalização, investimentos em ajuda externa podem ser utilizados como uma ferramenta para fortalecer facções que estão no poder. $O$ trabalho usa uma estimação em dois estágios para calcular o impacto dos fluxos de ajuda sobre a probabilidade de intensificação do conflito. Os resultados mostram que a ajuda externa pode contribuir para transformar pequenos conflitos em conflitos maiores, mas não dão evidência de que ela cria conflitos em 
países anteriormente pacíficos. 


\section{Abstract}

This thesis consists of three studies that investigate the political impacts of foreign aid investment, as well as the internal allocation strategies by the leaders of the recipient countries. Exploring different levels of analysis and sets of countries, they seek to contribute to the understanding of strategic choices made by donor countries and recipient leaders.

Chapter 1 explores how local leaders use foreign aid resources to perpetuate themselves in power. The findings show that in competitive elections, leaders direct resources to broaden their base beyond core voters. When elections are not competitive, leaders have less reason to doubt their political survival and direct resources to their ethnic districts. The availability of foreign aid information at the sub-national level is rare, and this study takes advantage of the release of new databases that systematize Chinese investments in Africa.

Chapter 2 adopts a more traditional level of analysis in foreign aid studies. Using data from 155 countries between 1960 and 2011, it investigates whether investment in foreign aid has heterogeneous effects in countries with democratic and authoritarian regimes. The results demonstrate that democratic countries allocate aid more effectively than authoritarian countries, but the estimates present robustness problems.

Chapter 3 investigates the possible impact of foreign aid on the intensity of civil conflict. In countries with a lower degree of institutionalization, foreign aid investments can be used as a tool to strengthen factions in power. The paper uses a two-stage estimation to calculate the impact of aid flows on the likelihood of conflict escalation. The results show that foreign aid can contribute to turning small conflicts into major conflicts, but they do not give evidence that it creates conflicts in previously peaceful countries. 


\section{Sumário}

1 Ajuda Externa e Favorecimento Eleitoral 10

1.1 Introdução . . . . . . . . . . . . . . . . . . . . . . 10

1.2 Literatura . . . . . . . . . . . . . . . . . 16

1.2.1 Política distributiva . . . . . . . . . . . 16

1.2.2 A Economia Política da Ajuda . . . . . . . . . . 19

1.3 Metodologia ..................... 23

1.4 Dados . . . . . . . . . . . . . . . . . . . . . . . 29

1.4.1 Estatística descritiva . . . . . . . . . . 33

1.5 Resultados . . . . . . . . . . . . . . . 33

1.6 Conclusão . . . . . . . . . . . . . . . . . 42

2 Regimes Políticos e a Efetividade da Ajuda Externa 47

2.1 Introdução . . . . . . . . . . . . . . . . . . . . 47

2.2 Literatura . . . . . . . . . . . . . . . . . . . 52

2.3 Hipóteses . . . . . . . . . . . . . . . . . . . . 57

2.4 Operacionalização e Dados . . . . . . . . . . . . . 58

2.5 Metodologia e Resultados . . . . . . . . . . . . . . . 60

2.5 .1 Estimador OLS . . . . . . . . . . . . . 61

2.5 .2 Efeitos Fixos . . . . . . . . . . . . 64

2.6 Discussão . . . . . . . . . . . . . . . . . . 65

3 Conflitos Civis e os Riscos da Ajuda Externa 68

3.1 Introdução . . . . . . . . . . . . . . . 68

3.2 Literatura . . . . . . . . . . . . . . . . . 71

3.3 Dados . . . . . . . . . . . . . . . . 76

3.3 .1 Controles . . . . . . . . . . . . 79

3.4 Estratégia Empírica . . . . . . . . . . . . . . . . 80

3.5 Resultados . . . . . . . . . . . . . . . 83

3.5.1 Estimação da Ajuda . . . . . . . . . . . . . 83

3.5 .2 Resultados ................. 86

3.5.3 Probabilidades de Transição . . . . . . . . . . . . 89

3.6 Conclusão . . . . . . . . . . . . . . . . . . . . 90 
Referências Bibliográficas 


\section{Lista de Tabelas}

1 Estatística Descritiva - 2000 a $2011 \ldots \ldots$. . . . . . . . . 34

2 Modelos BM-Distrito . . . . . . . . . . . . . 35

3 Efeitos Marginais BM . . . . . . . . . . . . . . . . 37

4 Efeitos Marginais Agregados . . . . . . . . . . . . . . 40

5 Modelo Completo: BM . . . . . . . . . . . . . . . . 45

6 Modelo Completo: Agregado . . . . . . . . . . . . . . 46

$7 \quad$ Efeitos da Ajuda e da Democracia sobre a Pobreza - OLS . . 62

8 Efeitos da Ajuda e da Democracia sobre a Pobreza - EF . . . 66

9 Probabilidades de Transição não Condicionadas ao Modelo . 78

10 Primeiro Estágio . . . . . . . . . . . . . . . . . . . . . 85

11 Segundo Estágio . . . . . . . . . . . . . . . 87

12 Efeito da Ajuda sobre a Probabilidade de Transição . . . . . 88

13 Probabilidades de Transição . . . . . . . . . . . . . . . . 89

14 Efeitos da Ajuda - Controles Adicionais . . . . . . . . . . . . 92 


\section{Ajuda Externa e Favorecimento Eleitoral}

\subsection{Introdução}

Este capítulo investiga a distribuição sub-nacional da ajuda externa da China e do Banco Mundial para identificar se os líderes usam esses recursos para fins políticos. Líderes políticos podem usar esses fundos para favorecer os seus grupos étnicos, a sua região de nascimento ou direcionálo a áreas em que há predominantemente eleitores oposicionistas, dependendo de qual estratégia se espera receber mais benefícios eleitorais (Cox e McCubbins, 1986; Kasara, 2007; Lindbeck e Weibull, 1987). A forma como os líderes políticos distribuem a ajuda pode depender do grau de competitividade eleitoral e sua certeza de ser reeleito (Hicken, 2011).

A literatura indica que a ajuda externa nem sempre é usada pelos países recipientes como era pretendido pelos doadores. Esta questão da fungibilidade da ajuda é exacerbada em ambientes de instituições de baixa qualidade, fraco estado de direito, falta de transparência nas transações e má administração dos recursos públicos (D. A. Bräutigam e Knack, 2004). Os principais destinatários dos fluxos de ajuda externa são os governos recipientes. Dado que eles têm mais informações do que os doadores, é possível imaginar que os governos beneficiários no poder têm autonomia para distribuir discricionariamente os recursos recebidos (Wright e Winters, 2010).

Isso cria incentivos para que os líderes políticos distribuam a ajuda 
externa de uma maneira que seja benéfica para eles, ou seja, em troca de apoio político e para maximizar sua proporção de votos e, consequentemente, tempo de posse no cargo (Licht, 2010; Masaki, 2018). A literatura sobre política distributiva oferece duas teorias sobre como os líderes políticos alocam recursos públicos para fins eleitorais: a hipótese do eleitor "core" e a do eleitor "swing" (Lindbeck e Weibull, 1987). Core voters são aqueles que apoiam o incumbente incondicionalmente (Cox e McCubbins, 1986). Swing voters, por sua vez, são aqueles que têm fraca preferência partidária, são indiferentes a votar em um líder político específico e podem, assim, ser facilmente influenciados a favorecer o incumbente (Lindbeck e Weibull, 1987). No contexto da África, no entanto, a etnia desempenha um papel vital na política, uma vez que os padrões de votação se baseiam em clivagens étnicas (Posner, 2007; Weghorst e Lindberg, 2013). A literatura indica que líderes políticos podem favorecer as regiões co-étnicas e distribuir recursos aos membros de seu próprio grupo étnico ou de sua região de origem (Kasara, 2007).

O favoritismo étnico ou político pode ser alcançado de várias formas: fornecendo empregos, bens e serviços, investimento, tributação favorável, ou, no contexto de ajuda externa, desviando projetos de ajuda para regiões onde os eleitores de "maior retorno" se beneficiariam (Kasara, 2007; Robinson e Verdier, 2013). Mirar em um grupo específico de eleitores pode ser considerado como um investimento por parte dos líderes, e os "retornos" podem ser entendidos como um número maior de votos recebidos pelo político (Cox e McCubbins, 1986). Este processo nos remete à ideia de 
"patronagem", definido por Weingrod (1968) como "as formas pelas quais os políticos distribuem empregos públicos ou favores especiais em troca de apoio eleitoral".

A literatura sobre ajuda externa tem se concentrado principalmente na alocação por parte dos doadores, e identifica que diferentes doadores têm diferentes motivações para oferecê-la. Por exemplo, os franceses são mais propensos a direcionar ajuda às suas ex-colônias (McKinley e Little, 1979). Agências multilaterais como o Banco Mundial (BM) recompensam o desenvolvimento institucional e boas práticas. Doadores bilaterais, como o Reino Unido ou os países escandinavos, concentram-se na necessidade dos recipientes, enquanto interesses estratégicos, como o acesso a recursos naturais ou antigas colônias, também são considerados importantes para doadores como os Estados Unidos. (Alesina e Dollar, 2000; Nunnenkamp e Thiele, 2006). A recente coleta de dados sub-nacionais de diferentes doadores e diferentes países beneficiários nos permite examinar a distribuição da ajuda no nível do recipiente - mais precisamente, podemos observar como os projetos de ajuda são alocados a diferentes províncias e distritos dentro países recipientes (Briggs, 2012, 2014; Dreher et al., 2016; Jablonski, 2014). O objetivo deste trabalho é explorar como os líderes políticos alocam a ajuda externa em seus distritos, e identificar em quais casos os motivos étnicos ou políticos prevalecem.

Os fluxos de ajuda externa vêm aumentando nos últimos anos, particularmente a partir de "novos" doadores, que não fazem parte do Development Assistance Committee da Organização para Cooperação e Desenvol- 
vimento Econômico (OCDE-DAC) (Dreher, Nunnenkamp, e Thiele, 2011; Manning, 2006; Woods, 2008). A ajuda de doadores como a China, Arábia Saudita e Venezuela tem sido chamada de ajuda "desonesta" (rogue), que é considerada não-democrática e não-transparente por minar as políticas de desenvolvimento estabelecidas pelos doadores tradicionais. Os estudos têm mostrado que a alocação de ajuda desses "novos" doadores seguem padrões diferentes dos tradicionais (Dreher e Fuchs, 2011; Dreher et al., 2011; Woods, 2008). Por exemplo, a necessidade econômica do recipientes ou a boa "qualidade institucional" não seriam recompensadas por esses doadores, enquanto os interesses estratégicos ou políticos são considerados mais importantes (Dreher et al., 2011).

Nessa linha, a ajuda chinesa é vista como influenciada por motivos relacionados ao comércio e ao acesso a recursos naturais nos países recipientes (Dreher et al., 2011; Tull, 2006). Um dos princípios da ajuda chinesa é o "respeito pela soberania sem pré-condições" (D. Bräutigam, 2011). Assim, os projetos chineses na África são vistos como ferramentas cujo principal interesse seria forjar uma parceria para comércio e investimento. A ajuda é dada sem contratos de monitoramento, e sua alocação sub-nacional é, portanto, definida pelos governos recipientes. Essas características tornam tais fluxos mais vulneráveis à captura política, servindo assim aos interesses e agendas dos líderes políticos (Manning, 2006). Por sua vez, a ajuda de doadores "estabelecidos", como o Banco Mundial ou o OCDE-DAC, são caracterizados como investimentos destinados a projetos específicos em que existe maior controle, com mais ferramentas contra 
uso explicitamente político (Dreher et al., 2016; Winters, 2010). Cabe notar, no entanto, que Jablonski (2014) e Masaki (2018) encontram evidências de que a alocação da ajuda do BM também é motivada por interesses políti$\cos$.

O objetivo deste estudo é investigar a possibilidade de motivações étnicas e/ou político-econômicas na atribuição sub-nacional de ajuda externa em um painel de 17 países africanos. Os líderes políticos podem alocar recursos para seus próprios eleitorados e para seu núcleo eleitores que apoiam o incumbente incondicionalmente. Por outro lado, os líderes podem ter como alvo eleitores indecisos, cujo "apoio político aos partidos da oposição pode ser influenciado, dependendo sobre os prêmios de desenvolvimento do governo" (Masaki, 2018). Alternativamente, os líderes políticos podem considerar que seus interesses serão maximizados se direcionarem recursos para suas regiões de nascimento. Este estudo centra-se principalmente nos fluxos de ajuda do Banco Mundial, que são subsequentemente comparados aos fluxos de ajuda da China para examinar se o grau de competitividade eleitoral faz com que líderes políticos distribuam os recursos de forma diferente por razões étnicas ou politico-econômicas.

De modo geral, a alocação de ajuda externa é examinada no nível do doador, e poucos estudos específicos se concentram em explorar os motivos políticos do recipiente (Briggs, 2012; Dreher et al., 2016; Jablonski, 2014; Masaki, 2018). Por exemplo, Jablonski (2014) examina a alocação sub-nacional da ajuda multilateral juntamente com estratégias eleitorais em todos os distritos quenianos, e encontra evidências em favor da hipó- 
tese do core voter e do favoritismo étnico, enquanto que, em um contexto semelhante, Masaki (2018) se concentra na Zâmbia e encontra evidências para apoiar a hipótese do swing voter. Dreher et al. (2016) se concentram em um grande número de países africanos e examinam a alocação subnacional da ajuda nas regiões em que os líderes nasceram. No entanto, não investigam incentivos eleitorais.

Em uma primeira análise, os resultados empíricos sugerem que a ajuda não é usada para fins políticos. No entanto, quando a competitividade das eleições é considerada, a ajuda do BM é direcionada para fora de distritos com core votes e co-étnicos. Em contraste, quando as eleições não são competitivas, a ajuda é dirigida apenas aos distritos da mesma etnia. Em uma segunda fase, considera-se a ajuda agregada tanto do Banco Mundial como da ajuda chinesa.

Curiosamente, as descobertas em ambientes políticos competitivos contradizem tanto ambas as hipóteses core e swing. No entanto, motivos políticos são encontrados, uma vez que as evidências sugerem que os líderes políticos procuram maximizar a sua proporção de votos, visando distritos que demonstram apoio à oposição. Esses são os distritos gerariam retornos eleitorais mais altos se o direcionamento da ajuda for bemsucedida. Estes resultados em ambientes competitivos estão de acordo com os resultados de Masaki (2018) para a Zâmbia, mas contradizem os de Jablonski (2014) para o Quênia. Em ambientes eleitorais não competitivos sem incentivos políticos fortes, os líderes preferem visar as suas regiões co-étnicas e todas as variáveis políticas são estatisticamente insignifican- 
tes.

\subsection{Literatura}

\subsubsection{Política distributiva}

A literatura de política comparada sugere que os líderes políticos são "egoístas", se preocupando principalmente com sua própria reeleição e com o avanço de sua agenda política (Nordhaus, 1975; Persson e Tabellini, 1999). Assim, políticos aumentam os níveis de investimento pouco antes eleições para maximizar os votos e conseguir a manutenção do cargo (Nordhaus, 1975). Embora o timing das eleições não seja relevante para os propósitos deste estudo, os resultados da literatura mostram que os líderes políticos articulam políticas públicas e mobilizam as receitas do governo para fins políticos (Block, 2002; Shi e Svensson, 2006).

O favoritismo político e o direcionamento de um nicho específico de eleitores podem ser alcançados de várias maneiras: fornecendo empregos, bens e serviços, investimentos e gastos, transferências redistributivas ou, no contexto de ajuda externa, desviando projetos de ajuda para determinadas regiões (Persson e Tabellini, 1999; Robinson e Verdier, 2013).

Este conceito de troca clientelista entre políticos e eleitores pode ser mais relevante em eleições altamente competitivas (Hicken, 2011; Lindberg e Morrison, 2008). Apesar disso, espera-se que a competição política limite práticas consideradas corruptas ou clientelistas (Persson, Tabellini, 
e Trebbi, 2003). Este estudo não se concentra em corrupção ou atividades ilegais, e se concentra nos favores e recursos fornecidos pelos líderes políticos em troca de votos.

Direcionar recursos para distritos da base política do incumbente pode ser considerado um desperdício (Stokes, 2005). Em vez disso, os core voters poderiam ser tomados como garantidos, e o líder poderia ter como alvo os grupos de eleitores que não estão ligados a quaisquer preferências políticas e ideologias partidárias, podendo, portanto, ser facilmente influenciados pelo clientelismo (Dixit e Londregan, 1996; Masaki, 2018). Eleitores swing são aqueles que dão a maior taxa de retorno eleitoral e são considerados os eleitores que apoiam fracamente a oposição, mas podem mudar seu voto dependendo dos benefícios que recebem (Cox e McCubbins, 1986; Dixit e Londregan, 1996; Masaki, 2018; Persson e Tabellini, 1999; Weghorst e Lindberg, 2013).

A evidência empírica é mista, dando suporte a ambas as teorias. Uma possível explicação poderia ser que líderes em diferentes países e regimes com características heterogêneas adotam estratégias eleitorais variadas. Por exemplo, Miguel e Zaidi (2008) examinam fundos do governo federal, enquanto Weinstein (2011) examina gastos, e ambos estudos encontram evidências para a hipótese do core voter. Jablonski (2014) também encontra evidência a favor da a hipótese do core voter para a alocação de ajuda no Quênia. Por outro lado, Banful (2011) descobriu que os líderes em Gana visavam distritos em que perderam na última eleição, fornecendo evidências contra a hipótese do core voter. Casas (2012) encontra evidências em 
favor da a hipótese do swing voter na Argentina usando medidas de gastos do governo.

Nascimento e favoritismo étnico também desempenham um papel significativo na política africana (Kasara, 2007; Weghorst e Lindberg, 2013). A identidade étnica na África pode assumir muitas formas e pode basearse na religião, linguagem ou afiliação tribal, e estas diferentes identidades étnicas na África permitem aos eleitores identificar com diversos grupos (Posner, 2007). Líderes podem favorecer regiões específicas investindo mais recursos em áreas de seu próprio grupo étnico ou em seu distrito de nascimento (Franck e Rainer, 2012). Em ambientes eleitorais competitivos, esta associação relaciona-se com mais força com a hipótese do core voter de Cox e McCubbins (1986) e Dixit e Londregan (1996), onde os eleitores centrais podem ser pensados como os aqueles que pertencem ao mesmo grupo étnico dos líderes políticos. Como explicado anteriormente, alguns dos principais eleitores têm preferências políticas alinhadas com as posições do candidato ou do partido e tais eleitores votariam em um candidato ou em um partido incondicionalmente por causa dessas posições.

A literatura sugere que a intensidade da luz noturna é maior nos locais de nascimento dos líderes políticos (Hodler e Raschky, 2014). A intensidade da luz no período noturno atua como uma proxy do desempenho econômico, uma vez que a luz artificial está associada a projetos de infra-estrutura de larga escala, como estradas, pontes ou edifícios. Burgess, Jedwab, Miguel, Morjaria, e Padr Miquel (2015) encontra evidências de favoritismo étnico no Quênia em relação a ruas pavimentadas. Por ou- 
tro lado, Kramon e Posner (2013) testam o favoritismo étnico em seis países africanos e encontram evidências apenas para algumas variáveis em determinados países, sugerindo que o favoritismo étnico não pode ser generalizado para todos as políticas públicas ou para todos os países da África.

\subsubsection{A Economia Política da Ajuda}

Da mesma forma que os líderes usam instrumentos de políticas públicas para seus próprios benefícios quando enfrentam eleições, a ajuda externa também pode ser usada para fins políticos. Este uso da ajuda por países beneficiários refere-se à questão da fungibilidade, em que a ajuda externa é utilizada de forma diferente dos objetivos que eram pretendidos pelos doadores. Pressupõe-se neste trabalho que o governo destinatário, e por extensão seus líderes, sejam responsáveis pela distribuição dos fluxos de ajuda nos distritos porque eles têm mais informações do que o doador e, em segundo lugar, porque eles são o primeiro canal de entrega da ajuda e são responsáveis pelo tratamento dos fundos (Wright e Winters, 2010).

B. B. d. Mesquita e Smith (2009) desenvolveram um modelo teórico e mostram que a ajuda externa pode ser usada como uma ferramenta política para recompensar as principais bases dos líderes políticos. Ajuda externa pode ser usada em troca de apoio político, por exemplo, para maximizar o voto, ou para diminuir o risco de não ser reeleito (Licht, 2010). 
Práticas de clientelismo em relação à ajuda externa podem ocorrer quando os líderes alocam recursos a distritos específicos, onde um pequeno grupo de eleitores vai se beneficiar e essa alocação seria independente da necessidade. Os líderes políticos têm o incentivo para usar a ajuda estrategicamente com base no interesse eleitoral, e canalizá-la para os distritos que resultam nos mais altos retornos eleitorais e políticos.

A literatura empírica sobre as estratégias eleitorais utilizadas pelos líderes políticos é rica em resultados. Alguns estudos mostram que os líderes direcionam a ajuda aos core voters (Briggs, 2012; Jablonski, 2014), ao passo que também há evidências de afastamento do eleitorado nuclear e de favorecimento eleitores indecisos e da oposição (Masaki, 2018).

Em um estudo de caso que envolve as eleições de 2000 em Gana e um projeto de expansão da infra-estrutura elétrica do BM, Briggs (2012) relata que os líderes visaram estrategicamente os core voters. Porém, o artigo foca em um único projeto de ajuda nas dez províncias. Jablonski (2014) se concentra no Quênia no período de 1993 a 2010. Os resultados sugerem que os líderes direcionam ajuda aos seus core voters, em distritos com maiores margens de vitória e maior número de votos para o incumbente. Core voters que apoiam fortemente o incumbente, capturados por um polinômio da margem da vitória, também são recompensados, enquanto os eleitores da oposição recebem menos ajuda.

Contrariando os resultados acima, Masaki (2018) se concentra nos distritos da Zâmbia entre os período 1991 - 2010. Este trabalho estima a atribuição de ajuda multilateral de três organizações doadoras com re- 
gressões Poisson, além de replicar a metodologia empírica de Jablonski (2014). Os resultados deste artigo, no entanto, contradizem a hipótese do core voter, e sugerem que os líderes alocam ajuda multilateral a distritos com eleitores da oposição, e longe de distritos com eleitores cativos do incumbente.

Há também alguns resultados mistos em relação ao favoritismo étnico. Jablonski (2014) também examina o favoritismo étnico e encontra evidências de que distritos co-étnicos são favorecidos. Por outro lado, Masaki (2018) encontra evidências de que distritos co-étnicos são tratados como distritos eleitorais centrais, e menos ajuda é direcionada para esses distritos.

Dreher et al. (2016) investigam se as ajudas chinesas e do BM estão sujeitas à captura de interesses políticos, estimando se os investimentos são direcionados para os distritos de nascimento dos líderes. Com base nas características da ajuda chinesa, os autores esperam que apenas ela esteja sujeita à captura, e seus achados empíricos concordam com suas hipóteses. Os autores usam a mesma base de dados que é utilizada neste trabalho, com um modelo OLS com efeitos fixos por ano e por país.

À luz dos estudos mencionados, o foco deste estudo é identificar, em primeiro lugar, se os líderes políticos usam a ajuda para fins políticos e, em segundo lugar, que estratégia eles tomam em consideração para a atribuição sub-nacional de ajuda externa. A ajuda multilateral do BM é considerada em primeiro lugar, sempre com a suposição de que a alocação da ajuda é definida pelo líder do executivo. Em seguida, utilizamos a ajuda 
agregada da China e do BM. A expectativa é que o uso para fins políticos seja ainda mais forte, com base nas características da ajuda externa chinesa mencionadas anteriormente.

Os líderes políticos podem visar distritos da sua base política, ou então core voters, que também podem ser pensados como regiões co-étnicas. Por outro lado, se os líderes acreditarem que seus principais eleitores votarão neles incondicionalmente e não quiserem desperdiçar recursos para garantir seus votos já seguros, eles poderão visar distritos que apoiam a oposição na tentativa de convencê-los a mudar de voto.

O efeito das eleições competitivas também é examinado. A forma como os líderes políticos visam os fluxos de ajuda pode depender da sua segurança de serem reeleitos, o que decorre do grau de competitividade. Os líderes provavelmente responderão de maneira diferente em ambientes de baixa ou nenhuma competição eleitoral, onde sabem que se reeleger é quase certo, comparado a ambientes de forte competição, onde cada voto conta (Hicken, 2011).

A base de dados constitui-se de um painel de 17 países africanos, usando um conjunto de dados geográficos e eleitorais. A amostra estudada é composta por 645 distritos no período de 2000 a 2011. Esses 17 países são escolhidos desde que tenham eleições durante o período examinado e que tenham recebido ajuda externa de ambos os doadores. Apesar da disponibilidade de dados para a China e o Banco Mundial, este trabalho se concentra de forma independente nos fluxos do Banco Mundial e, em seguida, somamos a ajuda de ambos os doadores. Essa escolha foi 
feita pois a variabilidade da ajuda chinesa é muito pequena, em comparação com o BM, com a maioria das observações tendo valores zero.

\subsection{Metodologia}

O objetivo deste estudo é investigar a alocação sub-nacional de ajuda externa para identificar em que medida os líderes a utilizam a ajuda externa para fins políticos, e quais as estratégias eleitorais que adotam.

Para responder a essas questões, adotamos a estratégia empírica de Dreher et al. (2016), em que o seguinte modelo é estimado:

$\log (\text { Ajuda } / \text { Pop })_{c i t}=\alpha_{c t}+\beta_{1}$ M.Vitoria $i$ cit $+\beta_{2}$ Favoritismo $_{c i t}+\Phi X_{c i t}+\epsilon_{c i t}$

em que:

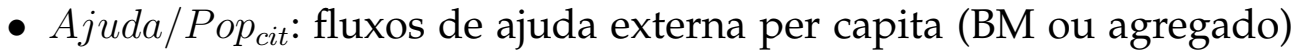
no país $c$, região $i$ e ano $t$

- M.Vitoria $a_{\text {cit }}$ : porcentagem de votos obtidos pelo incumbente menos a porcentagem de votos obtidos pelo principal partido de oposição no país $c$, região $i$ e ano $t$

- Favoritismo $o_{c i t}$ : Variável dummy que capturam o favoritismo regional: regiões co-étnicas 
- $X_{c i t}$ : Variáveis de controle

- $\alpha_{c t}$ : Efeitos fixos por país

Esses modelos são estimados com diversas variações para testar as diferentes estratégias eleitorais no nível do distrito. Um polinômio da margem da vitória também foi incluído na análise.

Entre as especificações alternativas, a variável que captura a margem de vitória é substituída primeiramente por uma variável que captura voto do incumbente - espera-se que essa variável tenha o mesmo sinal da margem de vitória. A segunda especificação alternativa substitui a margem de vitória por uma variável que captura o voto da oposição - e aqui se espera um sinal oposto ao das variáveis anteriores.

As hipóteses derivadas da literatura são as seguintes:

1. Hipótese do core voter: Examinamos se os distritos que apoiam o incumbente são recompensados por sua lealdade e apoio eleitoral.

2. Hipótese do swing voter: Examinamos se os distritos que podem mudar o voto recebem mais ajuda.

3. Oposição: Examinamos se os distritos que apoiam a oposição são ou não visados.

4. Favorecimento regional: As variáveis dummy são incluídas para investigar se os líderes políticos favorecem sua região de nascimento ou regiões co-étnicas. 
A amostra estudada inclui países cujo líderes ou partidos estão no poder há muito tempo. Por exemplo, o presidente de Angola, José Eduardo dos Santos, do Movimento Popular para a Libertação de Angola (MPLA), foi eleito em 1979 e serviu até 2017, período no qual as eleições executivas foram consideradas não-competitivas. A competitividade das eleições pode revelar-se importante nestes contextos. Líderes que sabem que vão ser eleitos tendem a direcionar a ajuda de uma maneira diferente do que os líderes que visam maximizar os votos para conseguir a reeleição.

A equação 1 é estendida para incluir termos de interação entre variáveis eleitorais e a competitividade, baseado no indicador da competitividade eleitoral do Executivo da Database of Political Institutions (DPI) (T. Beck, Clarke, Groff, Keefer, e Walsh, 2001). Na especificação da equação 2, duas dummies são incluídas para identificar os efeitos marginais. A primeira quando as eleições são considerado competitivas (Competitividade) e uma segunda identificando todos os demais casos (1 - Competitividade). 


$$
\begin{array}{r}
\log (\text { Ajuda } / \text { Pop })_{c i t}=\alpha_{c t}+\beta_{1} \text { M.Vitoria }_{c i t}+\beta_{2} \text { Favoritismo }_{c i t}+ \\
\beta_{3} \text { M.Vitoria }_{c i t} *\left(1-\text { Competitividade }_{c t}\right)+ \\
\beta_{4} \text { M.Vitoria }_{c i t} * \text { Competitividade }_{c t}+ \\
\beta_{5} \text { Favoritismo }_{\text {cit }} *\left(1-\text { Competitividade }_{c t}\right)+ \\
\beta_{6} \text { Favoritismo }_{c i t} * \text { Competitividade }_{c t}+ \\
\Phi X_{c i t}+\epsilon_{c i t}
\end{array}
$$

A equação 2 é ampliada da mesma forma que o modelo anterior: a margem de vitória é substituída em primeiro lugar pelo número de votos do incumbente, e em segundo lugar pelo número de votos da oposição.

Esses modelos nos permitem identificar que estratégia eleitoral os políticos adotam. Se os políticos favorecem seus eleitores centrais e querem recompensá-los por sua lealdade, o efeito da margem de vitória ou o número de votos do incumbente seria positivo (Cox e McCubbins, 1986; Dixit e Londregan, 1996; Jablonski, 2014). Se os líderes políticos favorecem fortemente seus eleitores, o coeficiente do polinômio da margem de vitória também seria positivo (Jablonski, 2014). Por outro lado, os líderes políticos podem acreditar que seus eleitores centrais votam incondicionalmente em sua chapa, o que os faz direcionar recursos para os swing voters ou mesmo para os eleitores da oposição (Licht, 2010; Moser, 2008). Políticos podem visar eleitores indecisos ou eleitores da oposição alocando recursos para 
eles com o propósito de atraí-los, e não deixar que votem em um rival. Nesses casos, o polinômio da margem de vitória seria negativo, ou o voto da oposição seria positivo, respectivamente. Os líderes também podem favorecer um local específico, desviando projetos de ajuda para um distrito ou porque é a sua região de nascimento, ou porque é preenchida por membros do seu próprio grupo étnico. Nos casos em que os líderes políticos favorecem regiões específicas, espera-se que a dummy capturando o favoritismo regional seja positivo.

Em ambientes competitivos, a probabilidade de ser reeleito é menor do que em ambientes não-competitivos, e essa incerteza pode resultar em líderes visando a oposição, distritos indecisos. Seguindo essa hipótese, os líderes poderiam desviar a ajuda dos distritos centrais. Espera-se, portanto, que o coeficiente da margem de vitória e da votação do incumbente seja negativo em ambientes competitivos. Essas hipóteses podem ser estendidas ao contexto de etnia, e assim, esperamos que o coeficiente de coetnia seja negativo em eleições competitivas. No entanto, em ambientes de baixa competição eleitoral, os líderes podem ter o luxo de se desviar das estratégias eleitorais ótimas, visando assim suas regiões co-étnicas.

O vetor de variáveis de controle incluídas nos modelos consiste em variáveis no nível do distrito, nomeadamente o tamanho da população $(\log )$ e a intensidade da luz noturna (log). Tamanho da população é uma variável de controle clássica na literatura, e é justificada por estudos que concluem que um contingente populacional grande pode ajudar a explicar maior alocação de ajuda (Öhler e Nunnenkamp, 2014). Além disso, se- 
guindo a literatura, a intensidade da luz noturna é usada como uma proxy para a atividade econômica em nível regional (Dreher et al., 2016; Henderson, Storeygard, e Weil, 2012; Hodler e Raschky, 2014). Infra-estrutura pública, por exemplo estradas ou pontes, ficam acesas durante a noite, o que pode ser capturado por esta variável. Em algumas especificações onde a ajuda do BM é a variável dependente, os fluxos de ajuda da China também são incluídos como controle. O controle é importante pois a alocação de ajuda pode depender de fontes alternativas de receita. Além disso, As decisões dos doadores sobre a quantidade de ajuda a ser alocada a cada país recipiente pode depender das decisões de outros doadores (Tierney et al., 2011).

Seguindo Dreher et al. (2016), a área dos distritos (log), bem como uma variável dummy identificando capitais estão incluídas. Finalmente, dummies para recursos minerais e petróleo são incluídos para capturar os efeitos dos recursos naturais na alocação de ajuda, assim como testar se os doadores destinam mais ajuda em regiões que podem satisfazer seus próprios interesses (Dreher e Fuchs, 2011).

Erros padrão são agrupados no nível do distrito para controlar qualquer autocorrelação dentro das regiões. A causalidade reversa não é um problema no modelo, uma vez que os resultados das eleições anteriores não dependem dos valores futuros da ajuda. 


\subsection{Dados}

\section{Limites administrativos}

O banco de dados Global Administrative Areas (GADM) inclui informações sobre os nomes e a área de seções administrativas do primeiro (ADM1) e segundo (ADM2) níveis. Esses níveis se referem a províncias (ADM1) e distritos (ADM2) dentro de cada país. Existem 221 regiões ADM1 que, por sua vez, contêm 645 regiões ADM2. Os 17 países para os quais temos dados são: Angola, Botsuana, Camarões, Cabo Verde, Gâmbia, Gana, Lesoto, Libéria, Malawi, Maurício, Moçambique, Serra Leoa, África do Sul, Tanzânia, Togo, Zâmbia e Zimbábue. Quando a base de dados do CLEA tem informações de eleição apenas até o primeiro nível administrativo, somente as regiões do ADM1 são considerados, mesmo que o banco de dados do GADM forneça informações sobre as regiões do ADM2.

\section{Ajuda externa}

Os dados de ajuda são obtidos no site do projeto AidData, que oferece informações sobre os fluxos de ajuda de diferentes agências. Dados para projetos do BM são livremente disponibilizados pela AidData para o período de 1995 a 2014, em que 5684 projetos de ajuda são georreferenciados para 61243 locais em todo o mundo (Tierney et al., 2011). Nos concentramos no período de 2000 a 2011, uma vez que as séries sobre os fluxos de ajuda para 2012 estão incompletas. 
Seguindo Jablonski (2014), utilizamos transferências com nível de precisão nível 5. Para construir a variável de ajuda de cada doador, os valores são somados com base na seguinte equação:

$$
A j u d a_{i t}=\sum\left(P 1_{i t}+P 2_{i t}+P 3_{i t}\right)+\sum\left(\left[P 4_{i t}+P 5_{i t}\right] * \frac{P o p A D M 2}{P o p A D M 1}\right.
$$

em que P1 corresponde aos fluxos de precisão 1, P2 corresponde aos fluxos de precisão 2, e assim por diante. Esta equação baseia-se no pressuposto de que os projetos alocados no nível da província beneficiam igualmente toda a população.

Para obter informações sobre o montante total de recursos regionais, adicionamos o valores de todos os projetos dentro de cada região. Há casos em que um projeto de ajuda é alocado para mais de um local. Em tais casos, assumimos que o projeto beneficia cada região igualmente. As variáveis de ajuda são convertidas para dólares constantes de 2009. A ajuda chinesa não é considerada isoladamente devido à baixa variação nos dados, em comparação com a ajuda do Banco Mundial.

\section{Variáveis políticas}

O Constituency-Level Elections Archive (CLEA) oferece resultados eleitorais detalhados no nível distrital para diferentes países (Kollman, Hicken, Caramani, e Backer, 2013). Algumas das informações que a base 
de dados oferece são o número total de votante, o total de votos depositados, o total de votos válidos, os votos recebidos por cada partido e cada candidato em cada distrito eleitoral para eleições legislativas em todo o mundo. ${ }^{1}$

\section{Líderes políticos}

Nós usamos a base de dados Archigos Goemans, Gleditsch, e Chiozza (2009) para identificar os líderes reais de cada país da amostra. A base fornece diversas informações sobre líderes políticos, por exemplo quando eles chegaram ao poder e como, sua região de nascimento e sua etnia. Nos regimes parlamentares, o líder efetivo é o primeiro-ministro, enquanto sistemas presidencialistas o líder efetivo é o presidente. Usando o conjunto de dados do Archigos foi possível identificar o distrito e a província em que cada líder político nasceu, assim como a etnia à qual pertence.

\section{Grupos étnicos}

Utilizamos a base Geo-Referencing Ethnic Power Relations (GeoEPR), construída por Vogt et al. (2015) para identificar o grupo étnico dos líderes.

Uma dummy é construída com valor de 1 quando uma região admi-

\footnotetext{
${ }^{1}$ Embora a maioria dos países em nossa amostra sejam regimes presidenciais, o CLEA fornece dados apenas para eleições legislativas. No entanto, na grande maioria dos casos, ambas as eleições ocorrem no mesmo ano, em que os mesmos partidos competem. As eleições executivas e legislativas ocorrem no mesmo ano para 15 dos 18 países da amostra.
} 
nistrativa é ocupada pelo grupo étnico do líder político, e 0 caso contrário. Em alguns casos, regiões administrativas têm mais de um grupo étnico. A limitação de usar o variável dummy de etnia é que nós não sabemos a proporção da população pertencente a diferentes grupos étnicos nessas regiões. Por isso, uma variável fictícia de co-etnicidade completa é construída. Co-etnia completa corresponde aos casos em que a região administrativa é ocupada por apenas um grupo étnico (a do líder político).

\section{Outras variáveis de controle}

A base de dados Time Lights da DMSP-OLS da National Oceanic and Atmospheric Administration (NOAA) é usada para capturar a intensidade da luz noturna.

Algumas variáveis no nível nacional são usadas para caracterizar o ambiente eleitoral dos países, como as variáveis do DPI T. Beck et al. (2001). A base de dados do DPI 2015 contém um índice de competitividade eleitoral, em que as eleições competitivas são definidas como aquelas cujo maior partido recebeu menos de $75 \%$ dos votos (valores de 7 no DPI). Valores abaixo de 7 podem correspondem a ambientes sem competição, por exemplo, quando há apenas um partido disputando as eleições, ou ambientes de baixa competição, onde, embora múltiplos partidos competem e ganham votos, o maior partido recebe mais de $75 \%$ dos votos. A dummy de competitividade eleitoral usada nos modelos assume o valor de 1 nos casos em que a medida de competitividade do DPI classifica as 
eleições como competitivos (valor de 7). Quando a variável dummy assume o valor de 0 , corresponde a casos de baixa ou nenhuma competição eleitoral.

\subsubsection{Estatística descritiva}

A Tabela 1 mostra as estatísticas descritivas para as variáveis de interesse na amostra de 4999 observações a nível distrital. Como pode ser visto na Tabela, a ajuda do BM é maior do que a ajuda chinesa. Os fluxos de ajuda agregada correspondem à soma da ajuda chinesa com a do BM. Cerca de 3\% dos distritos da amostra correspondem a regiões de nascimento de líderes políticos, e cerca de $40 \%$ dos distritos correspondem a distritos ocupados pelo seu grupo étnico, dos quais cerca de $11 \%$ correspondem a grupos totalmente co-étnicos. Cerca de 65\% dos distritos têm eleições competitivas. Nesses distritos, o tempo médio em que o partido está no poder é de 10 anos, enquanto para as eleições não competitivas a média é 25. Como esperado, essas estatísticas indicam a maior possibilidade de reeleição em ambientes de eleições não competitivos.

\subsection{Resultados}

A Tabela 2 mostra os resultados empíricos da equação 1, que inclui efeitos fixos e a ajuda do BM per capita como variável dependente. A regressão na coluna (1) inclui apenas o EF do país e a proporção de votos (margem de vitória / incumbente / oposição). Os controles geográficos ao 
Tabela 1: Estatística Descritiva - 2000 a 2011

\begin{tabular}{lccccc}
\hline \hline Variável & $\mathrm{N}$ & Média & D. Padrão & Min & Max \\
\hline Ajuda Chinesa & 4999 & 234707 & 4087960 & 0 & $1.21 \mathrm{e}+08$ \\
Ajuda Chinesa per capita & 4999 & 1.106 & 19.151 & 0 & 777.8 \\
Ajuda Banco Mundial & 4999 & 2981549 & $3.23 \mathrm{e}+07$ & 0 & $2.05 \mathrm{e}+09$ \\
Ajuda BM per capita & 4999 & 8.777 & 39.159 & 0 & 1395.164 \\
Fluxo Agregado de Ajuda & 4999 & 3216257 & $3.26 \mathrm{e}+07$ & 0 & $2.05 \mathrm{e}+09$ \\
Fluxo Agregado per capita & 4999 & 9.884 & 43.599 & 0 & 1395.164 \\
Margem de vitória & 4999 & 0.118 & 0.435 & -0.995 & 0.957 \\
Votos Incumbente & 4999 & 0.502 & 0.232 & 0 & 0.969 \\
Votos Oposição & 4999 & 0.447 & 0.217 & 0.015 & 0.998 \\
Região de nascimento & 4999 & 0.027 & 0.161 & 0 & 1 \\
Co-etnicidade completa & 4999 & 0.110 & 0.312 & 0 & 1 \\
Co-etnicidade parcial & 4999 & 0.293 & 0.455 & 0 & 1 \\
Competitividade & 4999 & 0.647 & 0.478 & 0 & 1 \\
Energia & 4999 & 4.894 & 1.678 & 0 & 61.951 \\
População & 4999 & 404284 & 981593 & 0.031 & $1.24 \mathrm{e}+07$ \\
Área & 4999 & 13173 & 31969.7 & 7.178 & 372916 \\
Capital & 4999 & 0.033 & 0.178 & 0 & 1 \\
Recursos Naturais & 4999 & 0.320 & 0.466 & 0 & 1 \\
Petróleo & 4999 & 0.030 & 0.171 & 0 & 1 \\
\hline
\end{tabular}

Estatísticas descritivas baseadas nas 4999 observações utilizadas na regressão. Ajuda externa medida em dólares constantes de 2009. 
Tabela 2: Modelos BM - Distrito

\begin{tabular}{|c|c|c|c|c|c|}
\hline & (1) & (2) & (3) & (4) & (5) \\
\hline \multirow[t]{2}{*}{ Margem de Vitória } & -0.003 & -0.014 & -0.023 & -0.022 & -0.022 \\
\hline & $(0.044)$ & $(0.044)$ & $(0.044)$ & $(0.044)$ & $(0.044)$ \\
\hline \multirow[t]{2}{*}{ Co-Etnicidade } & & & & -0.062 & -0.061 \\
\hline & & & & $(0.065)$ & $(0.065)$ \\
\hline \multirow[t]{2}{*}{ Margem de Vitória } & -0.004 & -0.015 & -0.024 & -0.021 & -0.022 \\
\hline & $(0.044)$ & $(0.043)$ & $(0.043)$ & $(0.044)$ & $(0.043)$ \\
\hline \multirow[t]{2}{*}{ Margem de Vitória Quad. } & 0.095 & 0.1 & 0.138 & $0.168^{*}$ & $0.168^{*}$ \\
\hline & $(0.089)$ & $(0.088)$ & $(0.086)$ & $(0.086)$ & $(0.086)$ \\
\hline \multirow[t]{2}{*}{ Co-Etnicidade } & & & & -0.093 & -0.092 \\
\hline & & & & $(0.064)$ & $(0.064)$ \\
\hline \multirow[t]{2}{*}{ Votos Incumbente } & -0.088 & -0.102 & -0.110 & -0.105 & -0.107 \\
\hline & $(0.088)$ & $(0.086)$ & $(0.087)$ & $(0.088)$ & $(0.088)$ \\
\hline \multirow[t]{2}{*}{ Co-Etnicidade } & & & & -0.058 & -0.057 \\
\hline & & & & $(0.065)$ & $(0.065)$ \\
\hline \multirow[t]{2}{*}{ Votos Oposição } & 0.006 & 0.027 & 0.046 & 0.042 & 0.043 \\
\hline & $(0.087)$ & $(0.085)$ & $(0.087)$ & $(0.088)$ & $(0.087)$ \\
\hline \multirow[t]{2}{*}{ Co-Etnicidade } & & & & -0.062 & -0.061 \\
\hline & & & & $(0.065)$ & $(0.065)$ \\
\hline Efeitos Fixos & Sim & Sim & Sim & Sim & Sim \\
\hline Controles - Geografia & Não & Sim & Sim & Sim & Sim \\
\hline Controles - Distritos & Não & Não & Sim & Sim & Sim \\
\hline Favoritismo Regional & Não & Não & Não & Sim & Sim \\
\hline Fontes Alt. Ajuda & Não & Não & Não & Não & Sim \\
\hline $\mathrm{N}$ & 4999 & 4999 & 4999 & 4999 & 4999 \\
\hline
\end{tabular}

Erros-padrões agrupados por distrito

${ }^{*} p<0.1,{ }^{* *} p<0.05,{ }^{* * *} p<0.01$ 
nível do distrito são adicionados na coluna (2), quais sejam, uma dummy para a capital, duas variáveis de recursos naturais e a área. Os controles de nível distrital são adicionados na coluna (3), população e intensidade luminosa. As regressões na coluna (4) incluem controles para as variáveis que testam o favoritismo regional: regiões de nascimento e regiões coétnicas dos líderes. E a coluna (5) acrescenta uma medida da ajuda chinesa como fonte adicional de fluxos de ajuda.

Os painéis das tabelas testam as hipóteses para diferentes estratégias eleitorais. No geral, as variáveis da margem de vitória, proporção de votos do incumbente, proporção de votos da oposição e a dummy de co-etnia completa são todos estatisticamente insignificantes. Os coeficientes para margem de vitória, proporção de votos e as regiões de co-etnia completa são negativos, enquanto o coeficiente da proporção de votos da oposição é positivo. O polinômio da margem de vitória é significativamente positivo nas colunas (4) e (5), com um coeficiente de 0,168. Estes resultados sugerem que os líderes políticos não alocam a ajuda do Banco Mundial de acordo com suas agendas políticas ou favoritismo étnico: os eleitores de base, os eleitores da oposição e as regiões co-étnicas não recebem mais recursos do que os outros eleitores.

A Tabela 3 mostra os efeitos marginais da equação 2, onde as variáveis políticas e a dummy de co-etnia estão interagindo com as duas dummies de competitividade eleitoral. Pode-se observar que os efeitos insignificantes da Tabela 2 são conduzidos principalmente por eleições não competitivas. 
Tabela 3: Efeitos Marginais BM

\begin{tabular}{|c|c|c|c|c|c|}
\hline & (1) & (2) & (3) & (4) & (5) \\
\hline M. Vitória*Não-Comp. & $\begin{array}{c}0.055 \\
(0.079)\end{array}$ & $\begin{array}{c}0.089 \\
(0.073)\end{array}$ & $\begin{array}{c}0.079 \\
(0.076)\end{array}$ & $\begin{array}{c}0.053 \\
(0.080)\end{array}$ & $\begin{array}{c}0.053 \\
(0.080)\end{array}$ \\
\hline M. Vitória*Comp. & $\begin{array}{l}-0.028 \\
(0.054)\end{array}$ & $\begin{array}{l}-0.058 \\
(0.054)\end{array}$ & $\begin{array}{l}-0.067 \\
(0.054)\end{array}$ & $\begin{array}{l}-0.070 \\
(0.054)\end{array}$ & $\begin{array}{l}-0.071 \\
(0.053)\end{array}$ \\
\hline Co-Etnicidade*Não-Comp. & & & & $\begin{array}{c}0.201^{*} \\
(0.111)\end{array}$ & $\begin{array}{c}0.200^{*} \\
(0.111)\end{array}$ \\
\hline Co-Etnicidade*Comp. & & & & $\begin{array}{l}-0.175^{*} \\
(0.070)\end{array}$ & $\begin{array}{c}-0.173^{*} \\
(0.070)\end{array}$ \\
\hline Incumbente*Não-Comp. & $\begin{array}{c}0.103 \\
(0.154)\end{array}$ & $\begin{array}{c}0.182 \\
(0.142)\end{array}$ & $\begin{array}{c}0.171 \\
(0.148)\end{array}$ & $\begin{array}{c}0.114 \\
(0.157)\end{array}$ & $\begin{array}{c}0.115 \\
(0.157)\end{array}$ \\
\hline Incumbente*Comp. & $\begin{array}{l}-0.173 \\
(0.108)\end{array}$ & $\begin{array}{c}-0.227^{* *} \\
(0.107)\end{array}$ & $\begin{array}{c}-0.235^{* *} \\
(0.108)\end{array}$ & $\begin{array}{c}-0.234^{* *} \\
(0.108)\end{array}$ & $\begin{array}{c}-0.236^{* *} \\
(0.107)\end{array}$ \\
\hline Co-Etnicidade*Não-Comp. & & & & $\begin{array}{c}0.195^{*} \\
(0.113)\end{array}$ & $\begin{array}{c}0.195^{*} \\
(0.112)\end{array}$ \\
\hline Co-Etnicidade*Comp. & & & & $\begin{array}{c}-0.172^{* *} \\
(0.069)\end{array}$ & $\begin{array}{c}-0.171^{* *} \\
(0.070)\end{array}$ \\
\hline Oposição*Não-Comp. & $\begin{array}{c}-0.104 \\
(0.153)\end{array}$ & $\begin{array}{l}-0.185 \\
(0.143)\end{array}$ & $\begin{array}{l}-0.165 \\
(0.149)\end{array}$ & $\begin{array}{l}-0.108 \\
(0.158)\end{array}$ & $\begin{array}{l}-0.109 \\
(0.158)\end{array}$ \\
\hline Oposição*Comp. & $\begin{array}{c}0.054 \\
(0.108)\end{array}$ & $\begin{array}{c}0.118 \\
(0.107)\end{array}$ & $\begin{array}{c}0.136 \\
(0.108)\end{array}$ & $\begin{array}{c}0.142 \\
(0.107)\end{array}$ & $\begin{array}{c}0.144 \\
(0.107)\end{array}$ \\
\hline Co-Etnicidade*Não-Comp. & & & & $\begin{array}{c}-0.199^{*} \\
(0.113)\end{array}$ & $\begin{array}{c}-0.198^{*} \\
(0.113)\end{array}$ \\
\hline Co-Etnicidade*Comp. & & & & $\begin{array}{c}-0.174^{* *} \\
(0.070)\end{array}$ & $\begin{array}{c}-0.173^{* *} \\
(0.070)\end{array}$ \\
\hline Efeitos Fixos & Sim & Sim & Sim & Sim & Sim \\
\hline Controles - Geografia & Não & Sim & Sim & Sim & Sim \\
\hline Controles - Distritos & Não & Não & Sim & Sim & Sim \\
\hline Favoritismo Regional & Não & Não & Não & Sim & Sim \\
\hline Fontes Alt. Ajuda & Não & Não & Não & Não & Sim \\
\hline $\mathrm{N}$ & 4999 & 4999 & 4999 & 4999 & 4999 \\
\hline
\end{tabular}

Erros-padrões agrupados por distrito

${ }^{*} p<0.1,{ }^{* *} p<0.05,{ }^{* * *} p<0.01$ 
Os efeitos da margem de vitória, proporção de votos do incumbente e proporção de votos da oposição são estatisticamente insignificantes nas eleições não competitivas. Os coeficientes da margem de vitória e da proporção de votos do incumbente são positivos, enquanto o coeficiente da proporção de votos da oposição é negativo. Nas eleições competitivas, entretanto, encontramos alguns resultados diferentes. O efeito marginal negativo da proporção de votos do incumbente sugere que os líderes políticos alocam menos ajuda para os distritos de seu núcleo em ambientes competitivos. Estes resultados indicam que os líderes políticos consideram seus core voters como garantidos: estão certos de sua lealdade e podem se dar o luxo de direcionar ajuda a outras regiões para maximizar seus votos. Essa interpretação também encontra guarida quando observamos a direção dos efeitos marginais da margem de vitória e da proporção de votos da oposição nas eleições competitivas, que são negativos e positivos, respectivamente.

No que diz respeito à etnia, consistente com os resultados para o apoio ao incumbente, em ambientes competitivos, os líderes políticos parecem direcionar a ajuda para fora de regiões completamente co-étnicas. Em contraste, em ambientes eleitorais não competitivos, os líderes preferem direcionar e favorecer suas regiões co-étnicas. Embora nessas regiões os principais eleitores do incumbente sejam os alvos em potencial, isso não pode ser visto como evidência em favor da hipótese dos core voters, já que nas eleições não competitivas a reeleição é um motivador mais fracos do que no caso de ambientes competitivos. A regressão completa, incluindo 
todos os controles, pode ser encontrada no anexo.

Até agora, a análise empírica se concentrou na ajuda do BM, um doador tradicional. O resultado de que a ajuda do BM é usado para promover as aspirações dos líderes não é surpreendente com base na literatura. Tanto Jablonski (2014) quanto Masaki (2018) supõem que os líderes têm autonomia para alocar toda a receita de ajuda conforme preferem. No entanto, ao analisar o padrão de ajuda de doadores "novos" e "emergentes" como a China, espera-se um aumento significativo dos padrões encontrados acima. Por isso, a mesma análise empírica é realizada para a ajuda agregada per capita como variável dependente. A Tabela 4 mostra os efeitos marginais nas eleições competitivas e não competitivas.

Os resultados com a ajuda agregada como variável dependente vão ao encontro dos achados anteriores, mas são um pouco mais fortes. Em particular, os resultados indicam uma associação negativa entre a margem da vitória e a ajuda agregada nas eleições competitivas. Além disso, o efeito marginal da proporção de votos da oposição torna-se significativamente positivo nas eleições competitivas. Este efeito positivo sugere que os líderes políticos visam maximizar o seu resultado eleitoral "atacando" os distritos da oposição. (Kasara, 2007; Stokes, 2005). Nas eleições não competitivas, os efeitos marginais permanecem estatisticamente insignificantes e seguem os mesmos padrões da ajuda do Banco Mundial.

No que diz respeito à etnia, o efeito significantemente negativo de distritos totalmente co-étnicos no BM desaparece quando se examina eleições competitivas. $\mathrm{O}$ fato de que a significância desaparece pode ser uma 
Tabela 4: Efeitos Marginais Agregados

\begin{tabular}{|c|c|c|c|c|}
\hline & $(1)$ & $\overline{(2)}$ & (3) & $\overline{(4)}$ \\
\hline M. Vitória*Não-Comp. & $\begin{array}{c}0.073 \\
(0.085)\end{array}$ & $\begin{array}{c}0.104 \\
(0.077)\end{array}$ & $\begin{array}{c}0.092 \\
(0.079)\end{array}$ & $\begin{array}{c}0.065 \\
(0.083)\end{array}$ \\
\hline M. Vitória*Comp. & $\begin{array}{c}-0.071 \\
(0.057)\end{array}$ & $\begin{array}{l}-0.101^{*} \\
(0.056)\end{array}$ & $\begin{array}{l}-0.110^{*} \\
(0.057)\end{array}$ & $\begin{array}{c}-0.112^{* *} \\
(0.056)\end{array}$ \\
\hline Co-Etnicidade*Não-Comp. & & & & $\begin{array}{c}0.202^{*} \\
(0.112)\end{array}$ \\
\hline Co-Etnicidade*Comp. & & & & $\begin{array}{c}-0.114 \\
(0.080)\end{array}$ \\
\hline Incumbente*Não-Comp. & $\begin{array}{c}0.139 \\
(0.168)\end{array}$ & $\begin{array}{c}0.214 \\
(0.150)\end{array}$ & $\begin{array}{c}0.199 \\
(0.155)\end{array}$ & $\begin{array}{c}0.142 \\
(0.165)\end{array}$ \\
\hline Incumbente ${ }^{*}$ Comp. & $\begin{array}{c}-0.262^{* *} \\
(0.112)\end{array}$ & $\begin{array}{c}-0.317^{* * *} \\
(0.111)\end{array}$ & $\begin{array}{c}-0.325^{* * *} \\
(0.112)\end{array}$ & $\begin{array}{c}-0.322^{* * *} \\
(0.112)\end{array}$ \\
\hline Co-Etnicidade*Não-Comp. & & & & $\begin{array}{c}0.195^{*} \\
(0.114)\end{array}$ \\
\hline Co-Etnicidade*Comp. & & & & $\begin{array}{l}-0.109 \\
(0.079\end{array}$ \\
\hline Oposição*Não-Comp. & $\begin{array}{c}-0.137 \\
(0.166)\end{array}$ & $\begin{array}{c}-0.212 \\
(0.150)\end{array}$ & $\begin{array}{c}-0.188 \\
(0.155)\end{array}$ & $\begin{array}{l}-0.130 \\
(0.165)\end{array}$ \\
\hline Oposição*Comp. & $\begin{array}{c}0.138 \\
(0.113)\end{array}$ & $\begin{array}{c}0.203^{*} \\
(0.113)\end{array}$ & $\begin{array}{l}0.223^{*} \\
(0.114)\end{array}$ & $\begin{array}{l}0.225^{* *} \\
(0.113)\end{array}$ \\
\hline Co-Etnicidade*Não-Comp. & & & & $\begin{array}{c}0.199^{*} \\
(0.114)\end{array}$ \\
\hline Co-Etnicidade*Comp. & & & & $\begin{array}{c}-0.113 \\
(0.080)\end{array}$ \\
\hline Efeitos Fixos & Sim & Sim & Sim & Sim \\
\hline Controles - Geografia & Não & Sim & Sim & Sim \\
\hline Controles - Distritos & Não & Não & Sim & Sim \\
\hline Favoritismo Regional & Não & Não & Não & Sim \\
\hline $\mathrm{N}$ & 4999 & 4999 & 4999 & 4999 \\
\hline
\end{tabular}

Erros-padrões agrupados por distrito

${ }^{*} p<0.1,{ }^{* *} p<0.05,{ }^{* * *} p<0.01$ 
indicação de que a ajuda chinesa é direcionada para distritos totalmente co-étnicos em ambientes competitivos, ao passo que a ajuda do BM é direcionada para outros distritos. O efeito positivo de distritos co-étnicos em eleições não competitivas, no entanto, ainda é válido. $\mathrm{O}$ favoritismo étnico é observado em nossa amostra e é encontrado em eleições nãocompetitivas, em que os líderes sabem que serão reeleitos; portanto, eles podem alocar recursos aos membros de seu próprio grupo étnico, em vez de tentar obter votos em outro lugar. Assim, o resultado do favoritismo étnico identificado na literatura empírica é apoiado por este trabalho apenas quando as eleições não são competitivas.

No geral, estes resultados contradizem ambas as hipóteses core e swing (Cox e McCubbins, 1986; Lindbeck e Weibull, 1987), bem como os resultados do favoritismo étnico na literatura no contexto de eleições competitivas. Uma possível explicação para estes resultados em ambientes competitivos é que os líderes políticos não querem desperdiçar recursos, visando distritos que sejam leais e que votem neles incondicionalmente, como regiões com seus principais eleitores ou membros de seu próprio grupo étnico (Kasara, 2007). Nos ambientes competitivos, os líderes políticos parecem estar direcionando a ajuda aos apoiadores da oposição para convencêlos a votar neles e maximizar sua proporção de votos, uma vez os eleitores co-étnicos são votos certos. Em contraste, nas eleições não competitivas, os líderes preferem direcionar recursos para distritos co-étnicos. 


\subsection{Conclusão}

Este estudo analisou se a agenda política dos líderes desempenha um papel importante para a atribuição de ajuda externa em todas as regiões administrativas. O objetivo do trabalho foi investigar a alocação subnacional da ajuda externa, na tentativa de identificar se e como a ajuda externa é usada pelas lideranças para fins políticos. Embora as características da ajuda chinesa permitam aos líderes usá-la de acordo com seus próprios interesses, esperava-se que a ajuda de ambos os doadores fosse manipulada para fins políticos, já que o chefe do Executivo é responsável pela alocação sub-nacional de recursos. Várias estratégias eleitorais foram investigadas: a hipótese do core voter, a hipótese do swing voter, bem como o favoritismo étnico e seu relacionamento com esses modelos.

Os resultados iniciais não encontraram nenhuma ajuda direcionada a distritos específicos, o que indicou que a ajuda não é utilizada para fins políticos. Considerando a competitividade eleitoral, os resultados sugerem que os líderes políticos usam o direcionamento de recursos quando se encontram diante de competição. A ajuda do BM é direcionada a distritos de eleitores core, e longe de ser co-étnica em ambientes competitivos. Nesta amostra de 17 países africanos, os líderes políticos preferem não desperdiçar seus recursos em sua base eleitoral. Em ambientes de eleições não competitivas, entretanto, prevalece o resultado de favoritismo étnico identificado na literatura.

Quando os fluxos de ajuda agregada são considerados, esperava-se 
que os resultados se tornassem mais fortes devido à exposição da ajuda chinesa à captura política. Esta hipótese é suportada pelos nossos resultados, que se tornam mais fortes em termos de significância. Líderes direcionam mais ajuda para os distritos de eleitores da oposição, possivelmente porque eles preferem concentrar a recursos em regiões que com potencial retorno eleitoral. A constatação de que os alvos são distritos da oposição, e não distritos indecisos, pode ser explicados pelas regras eleitorais. $\mathrm{Na}$ nossa amostra, a maioria dos países tem um sistema presidencial e em todos os casos o presidente é eleito por voto popular direto; ou seja, apenas o voto nacional é importante. Portanto, o Executivo pode achar ideal atingir um número maior de distritos com base em suas proporções de eleitores da oposição, em vez de visar um pequeno número de distritos marginais/swing (o que poderia ser o estratégia ideal quando a votação regional desempenha um papel importante para a eleição do executivo). Políticos favorecem suas bases apenas em ambientes de pouca ou nenhuma competição eleitoral.

Referente aos doadores "novos", os dados sobre os fluxos de ajuda apenas recentemente começaram a ser geo-codificados. Examinar a alocação da perspectiva do recipiente da ajuda pode ter implicações políticas importantes para doadores internacionais. Os resultados deste estudo contradizem a literatura que distingue entre doadores "emergentes" e tradicionais, encontrando resultados semelhantes em todos os grupos: a ajuda deles é usada para fins políticos. 
Anexo 
Tabela 5: Modelo Completo: BM

\begin{tabular}{|c|c|c|c|c|c|}
\hline & (1) & (2) & (3) & (4) & (5) \\
\hline M. Vitória*Não-Comp. & $\begin{array}{c}0.055 \\
(0.079)\end{array}$ & $\begin{array}{c}0.089 \\
(0.073)\end{array}$ & $\begin{array}{c}0.079 \\
(0.076)\end{array}$ & $\begin{array}{c}0.053 \\
(0.080)\end{array}$ & $\begin{array}{c}0.053 \\
(0.080)\end{array}$ \\
\hline M. Vitória*Comp. & $\begin{array}{l}-0.028 \\
(0.054)\end{array}$ & $\begin{array}{l}-0.058 \\
(0.054)\end{array}$ & $\begin{array}{l}-0.067 \\
(0.054)\end{array}$ & $\begin{array}{l}-0.070 \\
(0.054)\end{array}$ & $\begin{array}{l}-0.071 \\
(0.053)\end{array}$ \\
\hline Competição & $\begin{array}{c}-0.703 \\
(0.591)\end{array}$ & $\begin{array}{l}-0.693 \\
(0.592)\end{array}$ & $\begin{array}{c}-0.693 \\
(0.596)\end{array}$ & $\begin{array}{l}-0.697 \\
(0.597)\end{array}$ & $\begin{array}{l}-0.696 \\
(0.597)\end{array}$ \\
\hline Capital & & $\begin{array}{c}0.367^{* * *} \\
(0.095)\end{array}$ & $\begin{array}{c}0.194 \\
(0.127)\end{array}$ & $\begin{array}{c}0.153 \\
(0.133)\end{array}$ & $\begin{array}{c}0.153 \\
(0.133)\end{array}$ \\
\hline Recursos & & $\begin{array}{c}0.179^{* * *} \\
(0.047)\end{array}$ & $\begin{array}{c}0.178^{* * *} \\
(0.047)\end{array}$ & $\begin{array}{c}0.189^{* * *} \\
(0.047)\end{array}$ & $\begin{array}{c}0.189^{* * *} \\
(0.047)\end{array}$ \\
\hline Petróleo & & $\begin{array}{c}0.143 \\
(0.098)\end{array}$ & $\begin{array}{c}0.156 \\
(0.095)\end{array}$ & $\begin{array}{c}0.154 \\
(0.094)\end{array}$ & $\begin{array}{c}0.153 \\
(0.094)\end{array}$ \\
\hline Area & & $\begin{array}{c}-0.041^{* *} \\
(0.018)\end{array}$ & $\begin{array}{c}0.002 \\
(0.021)\end{array}$ & $\begin{array}{l}-0.001 \\
(0.021)\end{array}$ & $\begin{array}{c}0.000 \\
(0.021)\end{array}$ \\
\hline População & & & $\begin{array}{c}0.002 \\
(0.021)\end{array}$ & $\begin{array}{c}0.002 \\
(0.021)\end{array}$ & $\begin{array}{c}0.002 \\
(0.021)\end{array}$ \\
\hline Energia & & & $\begin{array}{c}0.222^{* * *} \\
(0.066)\end{array}$ & $\begin{array}{c}0.229^{* * *} \\
(0.066)\end{array}$ & $\begin{array}{c}0.231^{* * *} \\
(0.066)\end{array}$ \\
\hline Região & & & & $\begin{array}{c}-0.002 \\
(0.118)\end{array}$ & $\begin{array}{l}-0.003 \\
(0.119)\end{array}$ \\
\hline Co-Etnicidade*Não-Comp. & & & & $\begin{array}{l}0.201^{*} \\
(0.111)\end{array}$ & $\begin{array}{c}0.200^{*} \\
(0.111)\end{array}$ \\
\hline Co-Etnicidade*Não-Comp. & & & & $\begin{array}{c}-0.175^{* *} \\
(0.070)\end{array}$ & $\begin{array}{c}-0.173^{* *} \\
(0.070)\end{array}$ \\
\hline Ajuda Chinesa & & & & & $\begin{array}{l}-0.019 \\
(0.044)\end{array}$ \\
\hline Efeitos Fixos & Sim & Sim & Sim & Sim & Sim \\
\hline $\mathrm{N}$ & 4999 & 4999 & 4999 & 4999 & 4999 \\
\hline
\end{tabular}

Erros-padrões agrupados por distrito

${ }^{*} p<0.1,{ }^{* *} p<0.05,{ }^{* * *} p<0.01$ 
Tabela 6: Modelo Completo: Agregado

\begin{tabular}{lcccc}
\hline \hline & $(1)$ & $(2)$ & $(3)$ & $(4)$ \\
M. Vitória*Não-Comp. & 0.073 & 0.104 & 0.092 & 0.065 \\
& $(0.085)$ & $(0.077)$ & $(0.079)$ & $(0.083)$ \\
M. Vitória*Comp. & -0.071 & $-0.101^{*}$ & $-0.110^{*}$ & $-0.070^{* *}$ \\
& $(0.057)$ & $(0.056)$ & $(0.057)$ & $(0.056)$ \\
Competição & -0.695 & -0.685 & -0.684 & -0.688 \\
& $(0.592)$ & $(0.593)$ & $(0.598)$ & $(0.599)$ \\
Capital & & $0.412^{* * *}$ & 0.208 & 0.175 \\
& & $(0.092)$ & $(0.129)$ & $(0.134)$ \\
Recursos & & $0.171^{* * *}$ & $0.170^{* * *}$ & $0.178^{* * *}$ \\
& & $(0.048)$ & $(0.048)$ & $(0.047)$ \\
Petróleo & & 0.109 & 0.125 & 0.124 \\
& & $(0.097)$ & $(0.092)$ & $(0.092)$ \\
Área & & $-0.038^{* *}$ & 0.014 & -0.013 \\
& & $(0.019)$ & $(0.022)$ & $(0.022)$ \\
População & & & -0.006 & -0.006 \\
Energia & & & $(0.021)$ & $(0.020)$ \\
Região & & & $0.269^{* * *}$ & $0.275^{* * *}$ \\
Co-Etnicidade*Não-Comp. & & & $(0.066)$ & $(0.066)$ \\
Co-Etnicidade*Não-Comp. & & & & -0.022 \\
& & & & $(0.121)$ \\
Efeitos Fixos & Sim & Sim & Sim & Sim \\
N & 4999 & 4999 & 4999 & 4999 \\
\hline \hline
\end{tabular}

Erros-padrões agrupados por distrito

${ }^{*} p<0.1,{ }^{* *} p<0.05,{ }^{* * *} p<0.01$ 


\section{Regimes Políticos e a Efetividade da Ajuda Ex- terna}

\subsection{Introdução}

Investimento maciço em ajuda externa é um fenômeno relativamente novo. Apesar de haver precedentes históricos, a ideia de transmitir recursos a países menos desenvolvidos de maneira constante e sistemática ganha tração na segunda metade do século XX, após a Segunda Guerra. Apesar de sua história curta, os resultados encontrados na literatura questionam se essa é uma política já não deveria ter sido descartada. Estudos como o de Alesina e Dollar (2000) indicam um ceticismo crescente sobre os efeitos positivos da ajuda sobre o crescimento econômico dos países recipientes, e encontram mesmo efeitos negativos. Ferramentas como Investimento Direto ou aumento do fluxo de comércio têm efeitos muito mais claros sobre as economias de países subdesenvolvidos.

Ainda assim, países continuam investindo em ajuda externa: entre 1961 e 2011, o investimento quase quadruplicou (Figura 1). Este trabalho busca entender por quê. Desde o fim da Segunda Guerra Mundial, a ajuda externa tem papel central na política internacional de desenvolvimento. A despeito de temores de que o fluxo de ajuda externa sofreria forte atenuação a partir do fim da Guerra Fria, compromissos por parte de países e organizações internacionais para financiar intervenções de desenvolvimento em países pobres continuaram e até mesmo aumentaram (Wright e 
Winters, 2010). Iniciativas como as Metas de Desenvolvimento do Milênio, assim como interesses de países doadores, fizeram com que as iniciativas de ajuda externa mantivessem o fôlego nas últimas duas décadas.

Figura 1: Evolução da Ajuda Externa - 1961 a 2011

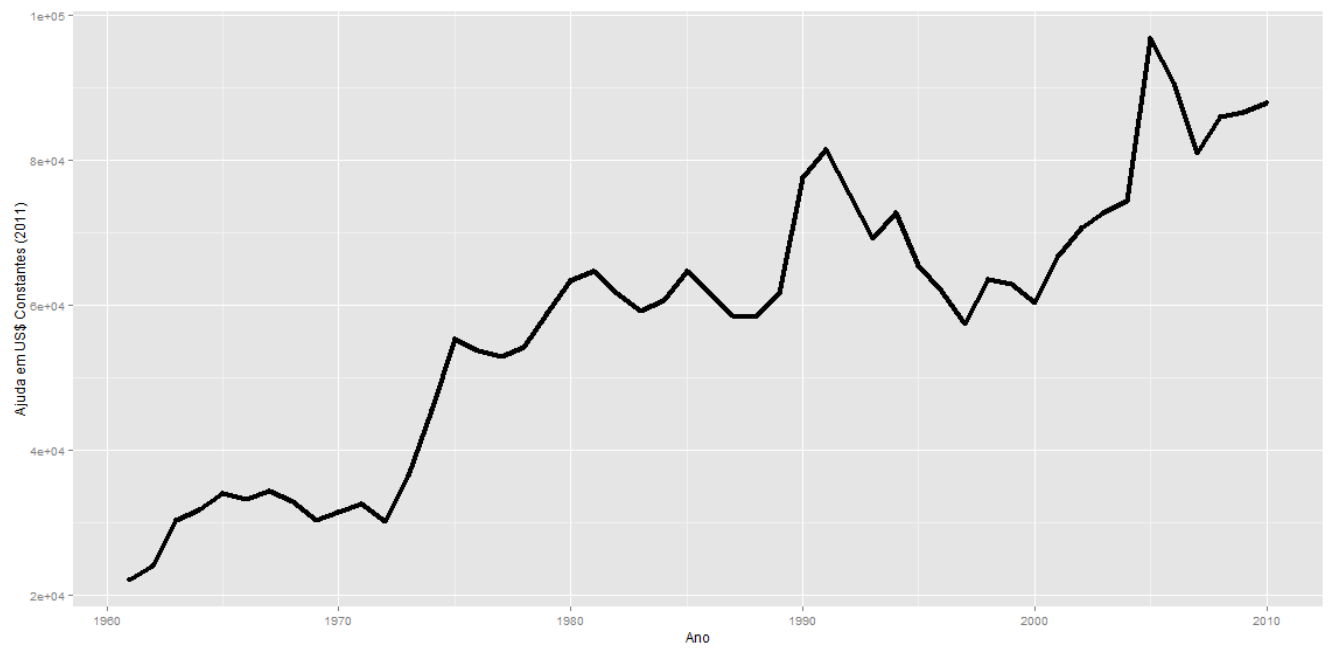

As principais ferramentas utilizadas atualmente para operacionalizar os fluxos internacionais de ajuda externa são a Assistência Oficial ao Desenvolvimento (ODA). No entanto, a estratégia de promoção econômica para países subdesenvolvidos mudou ao longo dos anos. Historicamente, o crescimento econômico foi promovido como a principal ferramenta de desenvolvimento, e por muito tempo pensava-se que o crescimento econômico persistente levaria a redução da pobreza, por si só. Ao longo das décadas, no entanto, o foco da agenda de desenvolvimento passou à promoção de projetos de infraestrutura de grande escala e, posteriormente, para a ideia da liberalização de mercados a partir da década de 1980. A década de 1990 viu um movimento para longe da agenda de ajuste estrutural, com ênfase nos direitos humanos e prestação de serviços bási- 
cos (Gilbert e Vines, 2006). Durante a última década, democracia e "boa governança" têm sido promovido como ferramentas para a eliminação da pobreza e a criação de crescimento econômico, mas a evidência empírica é inconclusiva (ver, por exemplo, Alvarez, Cheibub, Limongi, e Przeworski (2000), (Doucouliagos e Ulubalu, 2008)).

Apesar dessa longa história, a área de ajuda externa prossegue sendo uma das áreas substantivas de pesquisa nas ciências sociais em que o vão entre importância estratégica e avanço de agenda de pesquisa é dos mais salientes (Wright e Winters, 2010). Entre elas, a que gerou o debates mais frutíferos na área entre os anos 1990 e 2000 dizem respeito ao efeito da ajuda externa sobre o desenvolvimento econômico dos países recipientes. De forma análoga, mas em perspectiva inversa, outra questão que despertou o interesse de pesquisadores é a relação entre a doação de ajuda externa e os interesses estratégicos dos países doadores. Como veremos adiante, uma conclusão que emerge dos primeiros estudos sistemáticos sobre ajuda externa é a falta de efetividade desse investimento sobre os objetivos que, ao menos oficialmente, eles devem atingir. Com a constatação de que a ajuda externa tem baixo impacto sobre o desenvolvimento e com a observação empírica de países desenvolvidos investindo montantes cada vez maiores nessa política, aparecem os primeiros sinais de que a ajuda externa responde a necessidades de países doadores, não de países recipientes.

No discurso público, no entanto, a ajuda externa é promovida como uma das principais ferramentas para a erradicação da pobreza global. Ao 
longo das últimas décadas, a literatura desenvolvida por pesquisadores da Economia e da Ciência Política refinaram as constatações pessimistas daquela primeira onda de estudos, sem conclusões definitivas sobre os efeitos positivos ou deletérios de recursos doados de países desenvolvidos a países subdesenvolvidos. Pesquisadores têm debatido, desde os anos 2000, se a ajuda é boa para o crescimento econômico; se não tem nenhum efeito; ou se, de fato, prejudica o desenvolvimento econômico dos países recipientes (Radelet, 2006). O consenso formado por esses estudos é que a ajuda externa funciona em condições específicas (Burnside e Dollar, 2004; Collier e Dollar, 2002). A linha de pesquisa se desenvolve para a fase em que o mais urgente é especificar de maneira mais rigorosa que condições são essas, e quais delas otimizam o efeito positivo da ajuda. Há uma compreensão geral de ajuda externa como uma ferramenta eficaz na criação de crescimento quando certas condições estão presentes, indicando que a hipótese de uma relação linear entre ajuda e crescimento não é válida.

Este trabalho se propõe a investigar o efeito da democracia sobre a efetividade da ajuda externa, assim como examinar os mecanismos que podem explicar a heterogeneidade desses efeitos. A pergunta de pesquisa pode ser colocada da seguinte maneira: qual é e como se dá o efeito de instituições democráticas sobre a efetividade da ajuda em um país recipiente?

O trabalho se apoia em duas justificativas gerais sobre sua pertinência. A primeira diz respeito às condições para a eficácia da ajuda. A pesquisa sobre a eficácia da ajuda tem se atentado tradicionalmente em como 
as políticas econômicas afetam a eficácia da ajuda, e em grande medida ignorado a importância das instituições políticas. No entanto, a importância de liberdades políticas sobre a qualidade do padrão de vida de um país vem recebendo atenção crescente, destacando a necessidade de mais pesquisa na área (Banik, 2010). Instituições internacionais e países, especialmente ocidentais, estão com cada vez mais frequência condicionando fluxos de ajuda à reformas de democratização e ao aprimoramento de direitos políticos e liberdades civis. De fato, Alesina e Dollar (2000) encontraram evidências que suportam a afirmação de que países que se democratizam recebem mais ajuda.

A segunda justificativa diz respeito à importância de mecanismos subjacentes aos regimes democráticos que promovem maior efetividade da ajuda. Dadas a falta de robustez dos resultados disponíveis sobre a eficácia da ajuda, não só é importante esclarecer o efeito causal, mas os mecanismos por trás desses efeitos. É possível que a falta de resultados robustos seja atribuída a problemas de endogeneidade e baixa identificação das ferramentas econométricas aplicadas nos estudos dos anos 1990 e começo dos anos 2000. A identificação de mecanismos causais abre a possibilidade de tornar mais claros os efeitos de determinadas políticas e condicionalidades, tornando mais producentes os esforços sinceros de desenvolvimento.

Para efeito de definição, estão incluídos na categoria "ajuda externa"todos os projetos entre Estados que seja mediado por uma agência oficial e que tenha como fins imediatos o aumento do bem-estar social. Estão incluídos 
projetos de cooperação técnica, programas de promoção cultural (desde que ajudem a reforçar traços culturais do país recipiente) e programas de energia nuclear com finalidade civil). Não são incluídos programas de ajuda militar ou programas de manutenção de paz.

\subsection{Literatura}

Um dos motivos mais citados para a ineficácia da ajuda são a corrupção e a ignorância de líderes autocráticos (Ayittey, 2005; Kuznets, 1955; Meredith, 2007; Mundial, 1992). Tais líderes enxergam a ajuda como recursos a baixo custo para se distanciarem de sua população e aumentar sua própria riqueza pessoal e segurança. Morgenthau (1962) estava entre os primeiros a argumentar que a ajuda não contribuiu para mudanças políticas e sociais, por servirem apenas ao líder incumbente. Outros estudos empíricos têm mostrado que a ajuda ao desenvolvimento direcionada a regimes autocráticos têm efeito prejudicial ao bem-estar médio da população: por exemplo, ajudando o regime consolidar o seu poder através da corrupção e da exploração, em vez de investi-lo em políticas públicas eficazes (Levine e Roodman, 2003; B. B. Mesquita e Smith, 2005; Van der Walle, 2001; Wintrobe, 1990).

Parece plausível supor que um maior grau de transparência e $a c$ countability do governo levaria a um ambiente mais eficaz para eliminar a pobreza. Diferentes regimes fornecem diferentes incentivos sobre onde e quanto investir. Democracias e autocracias, portanto, alocam recursos de 
forma diferente. Os mecanismos políticos de uma democracia aumentam a probabilidade de que políticos egoístas saciem seu desejo de sobrevivência política por meio de provisão de bens públicos e distribuição de ajuda como uma maneira de arrematar votos. Em regimes autocráticos, os mecanismos políticos não conseguem providenciar o mesmo resultado pelo fato de a sobrevivência política não depender de eleições com concorrência crível. Assim, não há necessidade de os líderes autocráticos usarem recursos de ajuda externa como meio de obter votos. Assim, em democracias, líderes tendem a investir os recursos de ajuda externa em bens públicos, enquanto autocracias os investem na promoção de seu próprio poder.

Existem três grandes linhas de conclusões sobre a eficácia da ajuda sobre o desenvolvimento econômico de países recipiente: a) ajuda tem uma relação positiva com o crescimento econômico, b) a ajuda tem nenhum efeito sobre o crescimento econômico, e pode de fato ser prejudicial para o desenvolvimento, e; e c) ajuda tem uma relação condicional com o crescimento econômico, acelerando o crescimento em determinadas condições. A primeira categoria é constituída principalmente de estudos de caso, que descobriram que a ajuda tem, em média, funcionado em situações específicas (por exemplo Chenery e Eckstein (1970); RosensteinRodan (1961). No entanto, estudos de caso sofrem da falta de sistematização no tratamento das evidências, assim como na dificuldade de gerar inferências confiáveis sobre a generalização do efeito da ajuda. A segunda escola, por sua vez, é composta de um número relativamente pequeno de 
estudos, porém com grande influência no policy-making. Trata-se, na maioria dos casos, de estudos crosss-section que impõem suposições relativamente fortes sobre seus modelos, como característico da literatura econométrica da segunda metade do século passado. Esses estudos concluem, geralmente, pela falta de efeito da ajuda sobre o desenvolvimento (ver, por exemplo Boone (1994); White (1992)). A terceira escola de pensamento parece fornecer uma explicação de por que a ajuda tem funcionado em alguns casos e não em outros. Têm em comum com o segundo grupo a preponderância de estudos econométricos com grande quantidade de observações. Efeitos de interação nesses modelos não sobrevivem bem a testes de robustez, apresentando (ver, por exemplo Burnside e Dollar (2004); Collier e Dollar (2002)).

A década de 1990, em particular, viu uma nova geração de pesquisa aparecer, animada pelo trabalho de Boone (1994). Boone deu um novo rumo na pesquisa sobre a eficácia da ajuda através da inclusão de determinantes políticos da eficácia da ajuda, assim como por seu foco na relação entre ajuda, crescimento e políticas públicas em suas análises. Ele conclui que a ajuda não tem nenhum efeito sobre o crescimento ou investimento. $\mathrm{O}$ artigo analisa os efeitos da ajuda em diferentes tipos de regime: elitista, igualitário e laissez-faire. Regimes elitistas têm governos procuram maximizar o bem-estar da elite dominante; regimes igualitários procuram maximizar o bem-estar de sua cidadãos mais pobres, enquanto regimes laissez-faire procuram minimizar os impostos e as distorções do mercado. Ele encontra que regimes igualitários e democracias não usam recursos de 
ajuda externa de forma diferente do que os regimes elitistas ou laissezfaire. Todos os regimes tendem a usar a ajuda externa em políticas que estimulam o consumo, em detrimento de investimentos. No entanto, regimes democráticos têm taxas de mortalidade infantil substancialmente inferiores às de outros regimes. Boone aponta para duas implicações plausíveis de seus resultados: que apoio a regimes liberais é variável eficazes para a redução da pobreza e que existem fatores que afetam a efetividade da ajuda, sem, porém, afetar o tipo de regime.

Burnside e Dollar (2004) receberam muita atenção por abordarem o pessimismo do trabalho de Boone, bem como a falta de consenso de pesquisas anteriores (Levine e Roodman, 2003). Tratava-se, pelo menos em parte, de uma tentativa de chamar a a atenção para a condicionalidade das ajuda. O estudo encontra uma relação positiva entre ajuda e crescimento, mas apenas na presença de "boas políticas". Os autores afirmam (p. 847): "We find that aid has a positive impact on growth in developing countries with good fiscal, monetary, and trade policies but has little effect in the presence of poor policies". Para medir "boas políticas", os autores construíram um índice usando o excedente orçamental, a taxa de inflação e uma medida de abertura da economia desenvolvida por Sachs, Warner, Åslund, e Fischer (1995). Seu artigo tem sido um dos mais influentes sobre os efeitos da ajuda no crescimento econômico. De muitas maneiras, o foi fundamental na sua promoção da agenda liberal de desenvolvimento e implementação políticas econômicas sólidas como condição para a ajuda. $\mathrm{O}$ artigo contribuiu fortemente para uma compreensão geral de um au- 
mento na eficácia da ajuda na presença de políticas econômicas sustentáveis (ver, por exemplo Dalgaard e Hansen (2001); Hansen e Tarp (2000, 2001); Hudson e Mosley (2001); Lensink e White (2001); Levine e Roodman (2003); Lu e Ram (2001)).

A razão para as diferentes conclusões em Boone e Burnside e Dollar pode ser encontrada nos modelo de crescimento no qual se baseiam suas análises. Boone assume que já existe uma relação linear entre ajuda e crescimento, enquanto Burnside e Dollar tratam a relação como sendo nãolinear, através da introdução de um termo de interação entre a qualidade das políticas e a ajuda. Burnside e Dollar também apontam que o impacto da ajuda no crescimento está sujeito a retornos decrescentes, o que significa que o impacto da ajuda diminui depois de um certo ponto. Ao incluir um termo quadrático de ajuda, obtêm uma estimativa negativa estatisticamente significativa, indicando que a relação entre ajuda e crescimento não é apenas não linear, mas a apresenta uma queda na eficácia.

B. B. d. Mesquita e Smith $(2007,2009)$ aplicam a Selectorate Theory à alocação de ajuda externa. A inclusão de alterações institucionais endógenas na teoria significa que os autores a conseguem utilizar tanto para explicar a existência da ajuda quanto para analisar suas consequências políticas internas. Uma das implicações da Selectorate Theory no que diz respeito à ajuda externa é a sugestão de que práticas corruptas são uma parte essencial da decisão dos doadores para alocar recursos, bem como é do interesse de líderes corruptos receber ajuda (Bueno de Mesquita e Smith 2009, 335). Segundo o modelo formal dos autores, é mais fácil fazer cumprir 
concessões de políticas públicas impostas por agentes externos em países com pequenas coalizões vencedoras, refletindo esse sucesso de volta ao governo doador. A conclusão geral é que as transferências de ajuda em troca de concessões políticas prolongam a sobrevivência dos líderes de ambos os países beneficiários envolvidos no acordo, enquanto prejudicam os cidadãos da nação recipiente. Temos, portanto, a manutenção de líderes autocráticos no poder e a imposição de políticas que cuja demanda não parte da população (B. B. d. Mesquita e Smith, 2009). A este respeito, a Selectorate Theory apresenta um quadro deprimente sobre o efeito da ajuda na atenuação da pobreza.

\subsection{Hipóteses}

Concernente à primeira pergunta de pesquisa, qual seja, "o regime político afeta a efetividade da ajuda externa", a literatura aponta a existência de incentivos diferentes em democracias e autocracias para a utilização de recursos recebidos de entidades internacionais. Conforme apresentado na revisão de literatura, é de esperar que em democracias, governantes tenham maior propensão a investir recursos em boas políticas públicas, na medida em que elas aumentem a probabilidade de que seu grupo permaneça em postos de liderança. Democracias tendem a ter coalizões vencedoras amplas e são mais propensas a fornecer bens públicos do que autocracias, que tradicionalmente têm coalizões menores e têm preferência para alocar recursos do Estado para bens privados. A ajuda direcionada a países democráticos aumenta a disponibilidade e acessibilidade de água 
potável, de educação pública e de cuidados de saúde, fornecendo à população mais vulnerável as habilidades e segurança de que precisam para sair da pobreza

Portanto,

Hipótese 1a: Ajuda direcionada a democracias produzirá maior crescimento econômico do que aquela direcionada a autocracias

A mensuração da variável dependente tem papel central na captura do efeito. Há debate sobre o uso do PIB per capita como proxy de desenvolvimento econômico, e essas dúvidas são ainda mais relevantes para os objetivos expressos nos acordos de ajuda externa, que enfatizam sobretudo o combate à pobreza. Assim, derivamos uma segunda hipótese relacionada à primeira:

Hipótese 1b: Ajuda direcionada a democracias produzirá maior queda na pobreza do que aquela direcionada a autocracias

\subsection{Operacionalização e Dados}

- Variável dependente

- dados sobre crescimento econômico e níveis de pobreza de países recipientes são prontamente disponíveis no World Development Indicators (Mundial, 2014). Devido à restrição imposta pela disponibilidade de dados referentes à variável independente principal, o período que se pretende cobrir se estende de 
1960 a 2011;

- Variáveis independentes principais

- Dados sobre fluxo de Ajuda Externa são coletados e divulgados pelo Development Co-operation Directorate (DAC), da OCDE. Dados desagregados por ano estão disponíveis desde 1960, e permitem identificar projetos temáticos, perdão de dívidas e recipiente da ajuda;

- Dados sobre regimes políticos serão coletados do Polity Index e do projeto Democracy and Dictatoship Revisited (Cheibub, Gandhi, e Vreeland, 2010)

- Variáveis de controle

- População é uma variável que está historicamente associada ao fluxo de ajuda externa (Alesina e Dollar, 2000). A literatura indica que a população do país recipiente deve ser controlada para capturar o efeito de países pequenos, que recebem quantidade maior de ajuda com relação ao se PIB per capita (Burnside e Dollar, 2004)

- PIB per capita controla para o fato de que o fluxo de ajuda externa é concentrado em países menos desenvolvidos, Ademais, dado que há alta correlação entre PIB e democratização, a variável independente principal estaria mal identificada sem esse controle 
- Polarização étnica (J. D. Fearon e Laitin, 2003) mede a segregação entre diferentes grupos étnicos no país recipiente. Esta medida é justificada pelo fato de que maior polarização é associada a maiores níveis de violência política e a políticas públicas de pior qualidade

\subsection{Metodologia e Resultados}

Vimos acima que a relação entre ajuda externa e redução da pobreza é contestada. O problema de identificação é recorrente nas ciências sociais e exige razoável controle sobre o processo gerador dos dados. Como o presente trabalho se apoia em dados observacionais, coletados por terceiros e sem qualquer mecanismo de controle contra variáveis não observadas, a ambição de se isolar o efeito da ajuda externa ou da democracia sobre a pobreza deve ser atenuada.

Dadas as limitações impostas pela falta de controle sobre a manipulação dos dados, podemos tomar algumas medidas que nos permitam reduzir o problema de variáveis não observadas e de endogeneidade entre o nível de pobreza de um país e a quantidade de ajuda externa que ele recebe. O estimador Arellano-Bond responde razoavelmente bem aos desafios impostos pela proposta. Uma de suas características é subtrair os valores "correntes" das variáveis de seus valores em $t$-1, respondendo à suposição de que a ajuda é correlacionada com os níveis iniciais de pobreza (Hansen e Tarp, 2001). Espera-se que essa propriedade reduza a endoge- 
neidade do modelo. Por outro lado, a especificação desse modelo é complexa, já que tende a gerar estimadores voláteis, altamente dependentes do tipo de mensuração utilizado para capturar as variáveis de interesse. Para efeito deste trabalho, os modelos serão submetidos aos estimadores OLS e de Efeitos Fixos.

Para testar a hipótese de efetividade da ajuda externa condicionada ao nível democrático do recipiente, será necessário incluir um termo de interação entre essas duas variáveis no modelo. Um desafio é identificar corretamente a direção da causalidade, pois é possível que a quantidade de ajuda externa direcionada a um país seja, ela mesma, afetada pelo crescimento da economia do recipiente, ou pelo nível de pobreza existente. De fato, a endogeneidade de modelos pode ser o que impede a literatura de achar efeitos significantes de ajuda sobre o desenvolvimento.

\subsubsection{Estimador OLS}

O primeiro modelo proposto é um estimador OLS com correção de erros-padrão. Este é o modelo mais básico, aplicando menos restrições do que os outros estimadores propostos no trabalho. O estimador OLS produz resultados apropriados para variáveis dependentes contínuas, desde que sejam cumpridas, entre outras, as condições de independência entre as observações. A principal característica dos dados em painel, porém, é a repetição de observações (no caso deste trabalho, os países estudados). Ambas as propriedades temporais e espaciais dos dados em painel pro- 


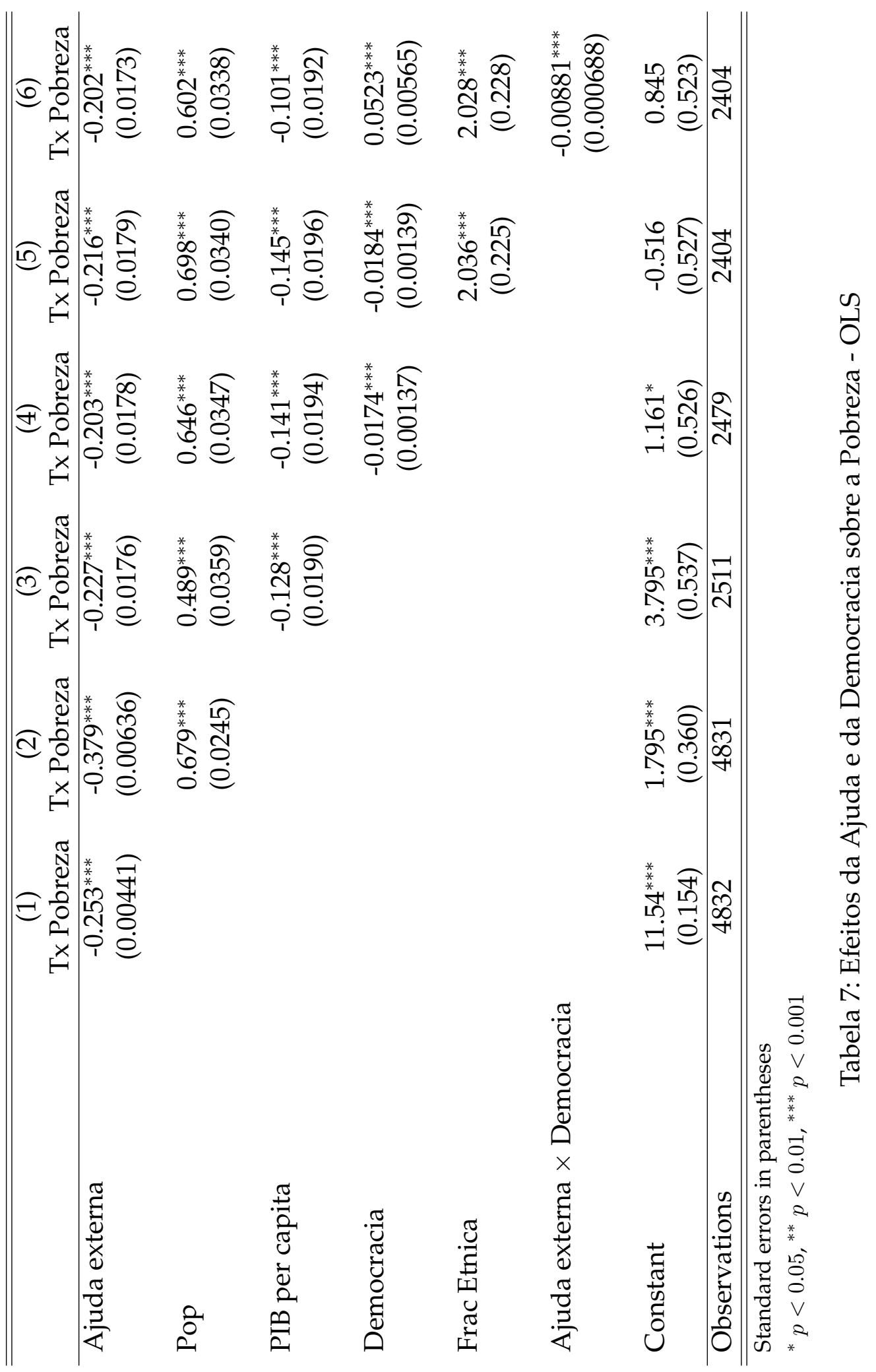


duzem problemas para o uso de estimadores OLS, pois geram interdependência entre as observações, as estimativas podem resultar enviesadas (Green, Kim, e Yoon, 2001).

N. Beck e Katz (1995) defendem que as estimativas de OLS em dados de painel muitas vezes têm boa performance, embora não sejam ótimas. Como os erros-padrão podem ser imprecisos com esses dados, eles propõem que sejam utilizados estimadores pontuais da OLS, conjuntamente com a introdução de erros-padrão corrigidos por painéis. No entanto, essa abordagem pode fazer com que os erros-padrão sejam sub- ou superestimados a depender da variação amostral, pondo em dúvidas a validade do teste.

Os resultados são apresentados na Tabela 7. Como esperado, a inclusão de novas variáveis no modelo aditivo não muda o sinal esperado entre elas, tampouco sua significância. As variáveis de ajuda externa e regime têm efeito negativo sobre o nível de pobreza dos países recipiente, mas o resultado que nos interessa de maneira mais imediata são o coeficiente e a significância do termo de interação. Através dele, pode-se observar que o efeito da ajuda condicionado ao regime é negativo, dando apoio à hipótese de que recipiente com instituições mais consolidadas conseguem um redução maior da pobreza quando comparados com regimes autocráticos. 


\subsubsection{Efeitos Fixos}

A suposição por trás da OLS é que as variáveis independentes controlam para quaisquer variações transversais à variável dependente, e se elas não são incluídas explicitamente no modelo é porque eles não estão correlacionadas com os preditores (condição de homocedasticidade). Para um desenho de pesquisa como o proposto, em que a unidade de análise é o país-ano, essa suposição provavelmente é violada. Os países são unidades altamente heterogêneas, com inúmeras características geográficas, históricas e culturais (entre outros) não observadas e potencialmente correlacionados com a variável dependente. Há ainda a possibilidade de algumas dessas variáveis estejam correlacionadas concomitantemente com níveis de pobreza, níveis de democracia e fluxo de ajuda externa, elevando o risco de viés de variável omitida.

O segundo estimador aplicado introduz, portanto, dummies de efeitos fixos que possibilitem o controle de variáveis não observadas específicas de cada país. Este estimador controla para variação não observada entre os países quando ela é constante durante todo o período de análise, além de correlacionada com as variáveis independentes no modelo. Enquanto na OLS todos os países têm o mesmo intercepto, com efeitos fixos atribui-se a cada país um intercepto próprio (Green et al., 2001). Os resultados deste modelo são exibidos na Tabela 8, e reforçam a robustez dos resultados encontrados no modelo discutido acima, especialmente no termo de interação. 
No entanto, os problemas de endogeneidade entre as variáveis pode fazer com que as estimativas dos modelos de Efeitos Fixos não sejam confiáveis, já que as variáveis incluídas no modelo serão correlacionados sistematicamente com o termo de erro. De fato, o estimador de efeitos fixos requer exogeneidade estrita das variáveis independentes em relação ao termo de erro. Se algumas das variáveis independentes no tempo $t$ estão correlacionados com um choque aleatório no tempo $t-1$, o estimador de Efeitos Fixos é inconsistente (Hansen e Tarp, 2001).

\subsection{Discussão}

A análise apresenta evidência de que a democracia promove a eficácia da ajuda através da realização de eleições contestadas, e através da presença de um nível mínimo de direitos políticos e liberdades civis para garantir a competitividade das eleições e a capacidade da população de exercer pressão sobre a liderança política e o governo. O desejo de sobrevivência política e o medo de não ser reeleito podem levar a um governo que aloca ajuda na medida em que é considerada necessária para a manutenção do cargo. A presença de eleições contestadas, com base em um nível mínimo de direitos políticos e liberdades civis, proporciona uma competição política que incentiva os líderes à efetiva alocação e implementação dos recursos recebidos.

No entanto, quando o governo não considera necessário obter o apoio de todos os segmentos da população, as eleições podem não funcionar de 


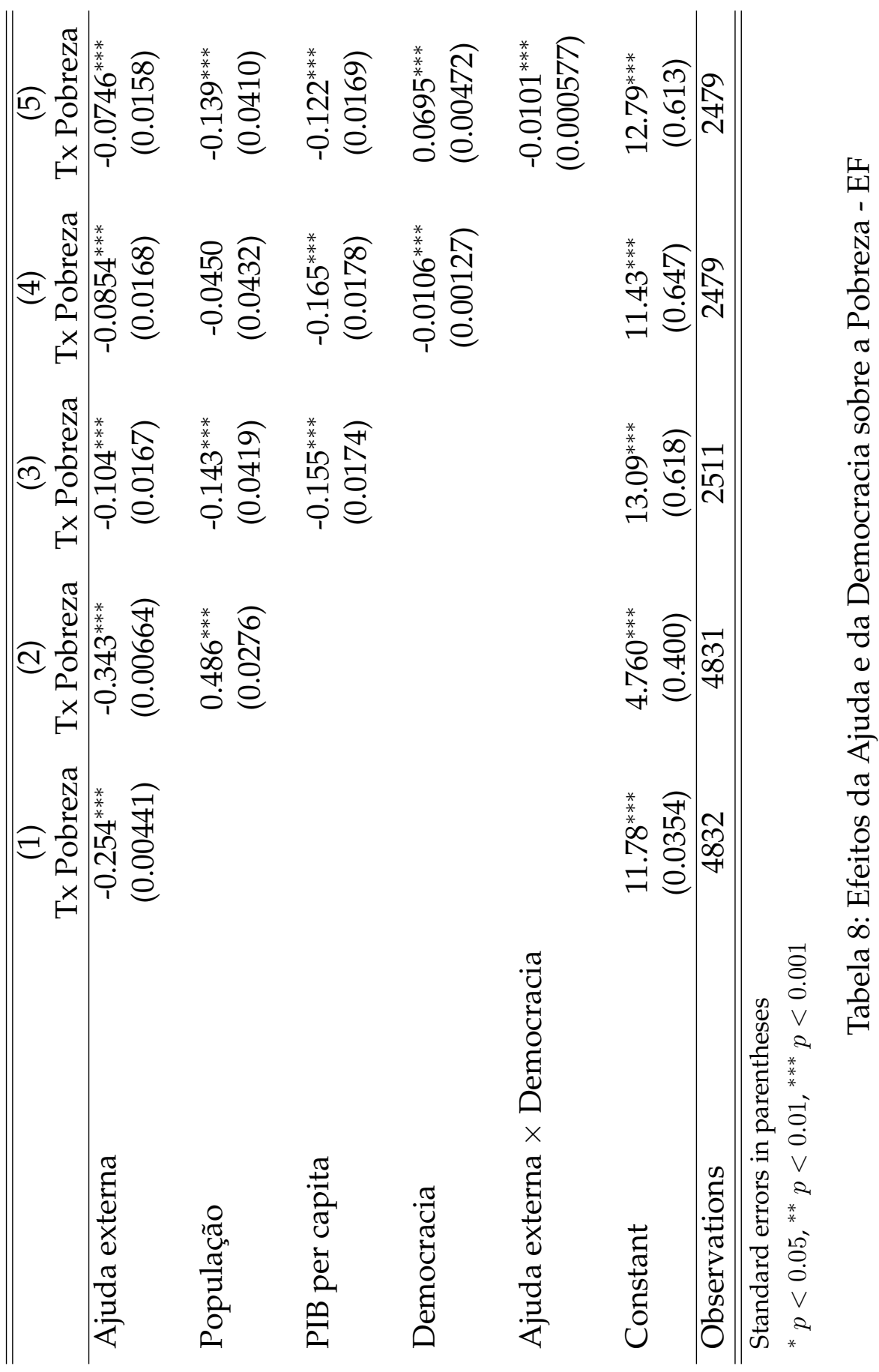


acordo com as suas intenções. É nesse momento que a importância dos direitos políticos e das liberdades civis, bem como a responsabilização e a transparência, se tornam ainda mais importantes, pressionando a necessidade de eleições verdadeiramente competitivas. Sem a presença de um mínimo nível dos direitos políticos e das liberdades civis, as eleições podem não só falhar na garantia de efetiva concorrência política. O governo também pode falhar em prestar contas a todos os segmentos da população.

Os resultados do trabalho indicam que a democracia leva a maior eficácia da ajuda através da realização de eleições contestadas e da presença de um nível mínimo de direitos políticos e liberdades civis. A competição política em torno dos votos que está presente em uma democracia e se origina da realização de eleições e de um nível mínimo de direitos políticos e liberdades civis, pode ser decisiva na efetiva alocação de ajuda na redução da pobreza. 


\section{Conflitos Civis e os Riscos da Ajuda Externa}

\subsection{Introdução}

O conflito civil é um dos principais obstáculos ao desenvolvimento. Pesquisas sobre as causas da guerra civil revelaram que baixo crescimento econômico, choques de commodities, instituições fracas e várias formas de heterogeneidade étnica estão todos correlacionados com conflitos. Estados pobres e mal governados são propensos a deflagrar conflitos civis, e recebem grandes fluxos de recursos sob a rubrica de assistência ao desenvolvimento. Uma literatura grande e crescente examina o efeito da ajuda externa no conflito civil, mas não conseguiu gerar um consenso sobre se a ajuda alimenta ou atenua os embates. Ambos os lados têm apoio teórico e empírico. Por um lado, existe a noção bem estabelecida de que a ajuda externa aumenta as receitas e, portanto, eleva o valor da captura do estado. (Grossman, 1991; Hirshleifer, 1989). Por outro lado, a ajuda externa pode aumentar o nível de provisão de bem público, que por sua vez aumenta o custo de oportunidade da violência (Collier e Hoeffler, 2004; Grossman, 1991), ou pode fortalecer a capacidade militar dos receptores (J. D. Fearon e Laitin, 2003).

A maior parte da literatura existente considera o conflito como um estado binário, mas distingue entre o início e a continuação do conflito, uma vez que estes podem ser motivados por diferentes fatores. Entretanto, estudar o início e a continuação do conflito separadamente é um substituto 
imperfeito para analisar um problema inerentemente dinâmico (N. Beck, Katz, e Tucker, 1998). Dividir a amostra não captura a ideia de intensificação ou atenuação entre diferentes níveis de conflito quando a natureza ordinal do conflito não é incorporada. Apenas o caso de uma mudança da paz para o conflito e vice-versa é geralmente contabilizada. Mas conflitos em pequena escala podem iniciar um ciclo de violência.

Este trabalho propõe desagregar os níveis de conflito e argumenta que negligenciar conflitos menores polui estimativas do efeito da ajuda externa. Para ver isso, considere o argumento de que a ajuda externa incita a violência porque alguns grupos lucram mais com os recursos do que outros. Hodler e Raschky (2014) e Dreher et al. (2016), por exemplo, mostram que os recursos tendem a fluir desproporcionalmente para a região de nascimento do atual governante. É provável que isso se traduza em descontentamento civil que pode encontrar sua expressão em atos menores de violência, com custos de oportunidade comparativamente baixos. Qualquer comportamento violento questiona o monopólio de violência do estado, satisfazendo o que pode ser considerado a definição mais básica de conflito civil. Pequenos conflitos atuam, portanto, como um sinal para o governo de que parte da sociedade não está contente com a atual provisão ou divisão de bens públicos. Além disso, eles ajudam potenciais rebeldes a obter uma estimativa de quão facilmente eles podem superar problemas de ação coletiva e fornecem informações vitais sobre as capacidades repressivas do governo (Acemoglu e Wolitzky, 2014; E. B. d. Mesquita, 2013). A ajuda externa, por sua vez, pode exacerbar tendências violentas 
em tais ambientes, mas talvez não quando a sociedade está em harmonia. Estabelecer como esse efeito difere nas histórias de conflito é o objetivo principal deste artigo.

Os resultados deste trabalho sugerem que o efeito da ajuda externa sobre as várias probabilidades de transição de conflito é heterogêneo e, em alguns casos, considerável. A ajuda externa pode ter um efeito muito diferente sobre a probabilidade de vivenciar um conflito, dependendo se a sociedade era inteiramente pacífica, já em turbulência, ou atolados em grandes conflitos civis.

A ajuda não prejudica os países receptores, causando conflitos em todos os setores. Enquanto todas as estimativas sugerem que a ajuda bilateral tende a alimentar o conflito, não encontramos evidências sugerindo que a ajuda externa leve a novas erupções de conflito ou que impulsione a escalada para (ou a continuação de) guerras civis. A ajuda é prejudicial quando concedida a países que já estão passando por turbulências. Nesses casos, encontramos um forte efeito negativo sobre a probabilidade de transição de volta para a paz; um risco elevado de violência continuada; e uma probabilidade não trivial de evoluir para um conflito armado. Assim como Burnside e Dollar (2004), que argumentam que a ajuda não é eficaz em países com políticas ruins, os resultados deste trabalho sugerem que a ajuda é contraproducente quando há turbulência violenta. 


\subsection{Literatura}

Pesquisadores geralmente pensam em ajuda externa e conflito civil em termos de duas hipóteses opostas. Uma hipótese é que a ajuda atenua, a outra é que ajuda a alimentar conflitos. A direção do efeito geral resume-se a como a ajuda altera o cálculo de cidadãos e governos. Para os cidadãos, a ajuda pode alterar os custos de oportunidade da luta (Becker, 1968; Collier e Hoeffler, 2004; Grossman, 1991). Para os governos, a ajuda pode aumentar a capacidade do estado (Besley e Persson, 2011a; J. D. Fearon e Laitin, 2003) e/ou aumentar o valor da captura do estado (Grossman, 1991). Variantes dessas teorias incorporam ambos os canais e tentam distinguir entre dois efeitos de renda opostos: ter menos para lutar, mas menos opções externas versus lutar por um bolo maior, tendo mais a perder (por exemplo, J. Fearon (2008), Besley e Persson (2011a)).

Ajuda externa afeta os custos de oportunidade de lutar. Se a ajuda melhora a provisão de bens públicos, então diminui diretamente os incentivos de se engajar em atividades violentas (Becker, 1968). A ajuda também pode alterar os custos de oportunidade indiretamente por meio do crescimento econômico. No entanto, a grande literatura empírica sobre ajuda e crescimento encontra pouca ou, na melhor das hipóteses, evidência fraca em favor desse canal (Clemens, Radelet, Bhavnani, e Bazzi, 2012; Rajan e Subramanian, 2008). A literatura sobre choques de renda e conflitos também é instrutiva. Bazzi e Blattman (2014) não encontraram nenhum efeito dos choques nos preços de exportação no início dos conflitos no nível nacional, enquanto Berman e Couttenier (2015) mostram que choques posi- 
tivos de renda têm um efeito estabilizador no nível subnacional.

A ajuda externa pode aumentar a capacidade do Estado. Quando a ajuda melhora os recursos públicos, é provável que o governo coloque mais esforços no controle desses recursos (J. D. Fearon e Laitin, 2003). Maior controle sobre os recursos aumenta sua capacidade de suprimir conflitos e maior capacidade do estado reduz o risco de conflito, reduzindo a probabilidade de uma captura bem-sucedida (Besley e Persson, 2011a). Assim, diminui o valor esperado da rebelião. Parte do efeito de capacidade do estado pode ser executado através de gastos militares. Embora a ajuda oficial ao desenvolvimento exclua a ajuda militar por definição, o recebimento de ajuda relaxa a restrição orçamentária do governo se a ajuda for suficientemente fungível. Embora os gastos militares mais elevados devam teoricamente reduzir o risco de conflito, a evidência empírica sobre este canal é mista. Collier e Hoeffler (2006) concluem que o aumento do gasto militar em estados pós-conflito aumenta a probabilidade de uma rebelião renovada, enquanto Dube e Naidu (2015) fornecem evidências do efeito da capacidade do Estado no nível micro. Eles descobriram que a ajuda militar dos EUA aumenta a violência de organizações paramilitares que funcionam como complementos às forças do governo na Colômbia, especialmente em anos eleitorais, mas não tem efeito perceptível sobre a guerra de guerrilha.

A ajuda externa aumenta as apostas. O estado é um preço que os rebeldes querem capturar, e o conflito se torna mais provável quando as receitas da ajuda são mais altas (Grossman, 1991). Tais argumentos são di- 
fundidos na literatura sobre conflitos por recursos naturais e muitos outros concursos. No entanto, como J. Fearon (2008)aponta, o nível de equilíbrio de conflito pode ser independente do nível de renda se os efeitos de receita e custo de oportunidade se anularem. Quando a ajuda age como um recurso inesperado em estados fracos, aumenta a violência e a repressão. Assim, importa onde a ajuda realmente vai e quão facilmente ela pode ser apropriada pelos rebeldes, seja diretamente interceptando entregas, ou indiretamente.

A maioria dos estudos que examinam o início ou a continuação do conflito civil encontra um efeito razoável da ajuda (De Ree e Nillesen, 2009; Savun e Tirone, 2011). No entanto, evidências em contrário têm se acumulado. Nunn e Qian (2014), por exemplo, sugerem que a ajuda alimentar, em particular, pode ser usada como financiamento rebelde, uma vez que pode (quase instantaneamente) ser capturada. Seus resultados mostram que a ajuda alimentar dos EUA prolonga a duração do conflito civil, mas não prevê seu início. Finalmente, mesmo os crescentes custos de oportunidade podem ser compatíveis com um efeito adverso da ajuda. Crost, Felter, e Johnston (2014) mostram que os municípios das Filipinas, que estão prestes a receber mais ajuda, aumentaram a atividade rebelde. Os rebeldes que antecipam essa mudança nos incentivos podem querer sabotar a ajuda se os programas de ajuda bem-sucedidos reduzirem o apoio à sua causa.

A natureza cíclica do conflito está recebendo atenção crescente. Teorias recentes visam explicar os ciclos de intensificação e atenuação das 
hostilidades em um arcabouço unificado. Besley e Persson (2011a) enfatizam que a violência unilateral de um incumbente com o objetivo de permanecer no poder dá origem a múltiplos estados de violência, que vão desde a paz, passando por pequenos conflitos, até a guerra civil. A literatura empírica fica atrás nesse sentido. Mesmo que os estudos sejam analisem diferentes níveis de intensidade, eles geralmente o fazem separadamente.

Pequenos conflitos são importantes para uma compreensão adequada dos ciclos de conflito. Eles são frequentemente o ponto de partida para uma escalada maior e podem ser parte integrante das táticas rebeldes (E. B. d. Mesquita, 2013). Os modelos de economia política destacam a importância da ação coletiva e dos problemas de informação que devem ser superados para se envolver em violência organizada, revolução ou guerra civil. Pequenos conflitos podem ajudar a superar esses problemas, fornecendo uma estimativa de quantos outros estão dispostos a lutar contra o governo. Teoricamente, pequenos conflitos podem ser considerados um dispositivo de sinalização, onde os potenciais rebeldes tentam determinar o tipo de governo ou vice-versa (Acemoglu e Wolitzky, 2014). Pequenas ações violentas não têm os mesmos custos de oportunidade que a guerra civil. Eles permitem que grupos de indivíduos questionem a autoridade sem investir muito na luta e podem ser substitutos estratégicos da guerra convencional em uma rebelião longa (E. B. d. Mesquita, 2013).

A negligência de pequenos conflitos é particularmente preocupante quando se trata do impacto da ajuda no conflito. O efeito da ajuda pode 
muito bem ser heterogêneo e depender do nível de violência. Esse poderia ser o caso por pelo menos dois motivos. Em primeiro lugar, a ajuda não é neutra em termos de distribuição. Maiores fluxos de ajuda podem aumentar o descontentamento pré-existente sobre a alocação de recursos. Devido a razões logísticas, a ajuda é dada com maior frequência a regiões ou regiões pacíficas de baixa intensidade de conflito. Se a ajuda é direcionada principalmente para essas regiões, o ressentimento pode se fortalecer em áreas sem privilégios, onde a violência persiste. Os custos de oportunidade se desgastam e os rebeldes que controlam essa região podem recrutar outros com mais facilidade. Em segundo lugar, se um país é totalmente pacífico, é menos provável que o governo desvie a ajuda para o desenvolvimento ou liberte recursos para as forças armadas. Se houver um conflito persistente, por outro lado, o governo em exercício pode continuar a investir nas forças armadas para reprimir ou desencorajar a rebelião (Besley e Persson, 2011a). Portanto, o efeito da ajuda na capacidade do Estado difere dependendo do nível de violência.

O nexo entre ajuda e conflito torna a identificação causal notoriamente difícil. A forte correlação entre baixo PIB per capita e conflitos civis é uma das descobertas mais robustas da literatura (Blattman e Miguel, 2010; J. D. Fearon e Laitin, 2003). O subdesenvolvimento - com tudo o que isso implica - é a razão de ser da ajuda ao desenvolvimento. Como resultado, o efeito da ajuda provavelmente será enviesado para cima se a ajuda for dada principalmente aos países necessitados, ou forçada para baixo se os doadores forem movidos por motivos políticos (conforme documentado, 
por exemplo, por Kuziemko e Werker (2006) e Dreher et al. (2016)). Os enviesamentos também podem resultar de terceiros fatores que influenciam a ajuda e os conflitos simultaneamente, como crises políticas e econômicas, ou erros (sistemáticos) de medição.

Grande parte da literatura segue Clemens et al. (2012) e aborda o problema da endogeneidade com uma defasagem na ajuda. Isso serve para descartar a causalidade reversa e evitar instrumentos de baixa qualidade. Outros seguem o conselho de Blattman e Miguel (2010) e focam na identificação causal com instrumentos individuais. Contudo, a maioria dos instrumentos propostos é acusada de não ser verdadeiramente exógena: De Ree e Nillesen (2009), por exemplo, usam o PIB do país doador para instrumentalizar fluxos de ajuda que poderiam funcionar através de diversos outros canais, como comércio ou investimento externo. Este trabalho segue Dreher e Langlotz (2017), que introduzem o fracionamento político como um instrumento para os fluxos de ajuda bilateral para estimar seu efeito sobre o crescimento econômico.

\subsection{Dados}

O trabalho analisa a ocorrência de violência civil em 125 países em desenvolvimento no período de 1975 a 2010. A seguir é apresentada a medida de conflito e, em seguida, a operacionalização da ajuda e das covariáveis.

Uma característica da literatura sobre conflitos civis é a sua medida 
binária de conflito. O padrão é primeiro contar o número de mortes relacionadas à batalha e então criar variáveis dummy indicando a ultrapassagem de um dos dois limiares (25 ou 1.000 mortes) pela primeira vez (início de conflito) ou para qualquer ano diferente do primeiro (continuação ou finalização).

Utilizamos uma medida ordinal de conflito com quatro estados. Para comparabilidade, inicia-se com a medida padrão de conflito civil UCDPPRIO (Gleditsch, Wallensteen, Eriksson, Sollenberg, e Strand, 2002). O UCDPPRIO define conflito civil como uma contestação que diz respeito ao governo ou a um território no qual a violência entre duas partes, uma das quais é o governo, resulta em pelo menos 25 mortes por ano. Conflitos que chegam a esse estado, mas não excedem 1.000 mortes em um determinado ano, são chamados de "conflito armado". No topo, adicionamos uma categoria chamada "guerra civil"se houver mais de 1.000 mortes. Besley e Persson (2011b) adotaram uma abordagem semelhante quando acrescentaram a repressão unilateral do Estado como uma categoria intermediária ao que definimos como guerra civil. A ideia por trás da variável ordinal é direta. Apenas uma sociedade verdadeiramente pacífica é codificada como zero. Nossa medida assume o valor de um se pelo menos uma variável no banco de dados exibir um valor positivo, mas menor que 25 mortes. As próximas duas categorias seguem a medida UCDP-PRIO. Conflitos com um mínimo de 25, mas menos de 1.000 BDs são codificados como dois, enquanto a categoria de guerra civil, ou seja, mais de 1.000 BDs, assume o valor de três. Como um todo, os países da amostra gastam cerca de um 
terço de todos os anos em conflito em várias intensidades e cerca de dois terços de todos os anos em paz.

Uma vantagem fundamental dessa abordagem é que o número de conflitos armados e guerras civis na amostra é idêntico à medida UCDPPRIO. Portanto, os resultados são comparáveis aos estudos existentes e diferem principalmente devido à definição de paz. Essa abordagem simples de mudar as medidas existentes implica que a nova medida ordinal é comparável e fácil de entender. Evita procedimentos de ponderação, assim como misturar variáveis de fluxo e estoque para medir diferentes intensidades de conflito, como tomar o montante acumulado de mortes para criar níveis intermediários de conflito civil armado (Bazzi e Blattman, 2014).

Tabela 9: Probabilidades de Transição não Condicionadas ao Modelo

\begin{tabular}{ccccc}
\hline \hline & \multicolumn{4}{c}{ Transição para: } \\
& Paz & Hostilidades & Conflito Armado & Guerra Civil \\
\hline Paz & 87.26 & 10.69 & 2.06 & 0 \\
Hostilidades & 43.85 & 48.13 & 6.78 & 1.24 \\
Conflito Armado & 11.28 & 8.46 & 70.30 & 9.96 \\
Guerra Civil & 1.49 & 5.97 & 23.88 & 68.66 \\
\hline \hline
\end{tabular}

A Tabela 9 mostra as probabilidades de transição incondicionais, antes de qualquer modelo. Este exercício simples permite fazer três pontos. Primeiro, a natureza cíclica dos conflitos é claramente visível. As probabilidades de comutação mais altas estão sempre na próxima categoria adjacente, mas as chances de atenuação nas categorias abaixo são sempre maiores que as de intensificação para as categorias acima. De fato, não há um único país em que a paz precedeu imediatamente a guerra civil. Em 
segundo lugar, a codificação de pequenos conflitos alcança uma separação importante da categoria inferior. A paz é muito persistente e, no mínimo, é provável que haja uma transição para um pequeno conflito. Um pequeno conflito é um estado frágil que muitas vezes volta à paz, não é particularmente persistente, mas às vezes explode em estados mais violentos. Terceiro, os conflitos de maior intensidade são novamente mais persistentes. Essas observações combinam bem com a discussão na seção anterior, em particular, o uso de meios irregulares para aumentar a mobilização para uma futura campanha convencional e a crescente persistência de oportunidades externas (E. B. d. Mesquita, 2013).

\subsubsection{Controles}

As principais variáveis independentes são dois tipos de fluxos desembolsados por 28 doadores bilaterais do Development Co-operation Directorate (DAC) da OCDE: Ajuda Oficial ao Desenvolvimento (ODA) e Outros Fluxos Oficiais (OOF). ODA refere-se a fluxos que: são fornecidos por agências oficiais a países em desenvolvimento e instituições multilaterais; têm desenvolvimento econômico e bem-estar como seu objetivo principal; e têm caráter concessional. OOF inclui fluxos pelo setor oficial com um elemento de doação de menos de 25 por cento ou fluxos que não são principalmente destinados ao desenvolvimento.

Para o conjunto de controles centrais, seguimos Hegre e Sambanis (2006), incluindo o registro da população para capturar o efeito de es- 
cala inerente à incidência de conflitos e ao log do PIB. Também usamos a pontuação do Polity IV para dar conta da qualidade institucional, ou um dummy da democracia indicando se a pontuação do Polity é igual ou maior que seis. É incluída uma medida de instabilidade política, isto é, uma dummy codificada se um país experimentou uma mudança em sua pontuação de Polity de pelo menos três pontos (Gates, Hegre, Jones, e Strand, 2006). Também incluímos a pontuação regional de Polity para representar os valores democráticos da vizinhança (Gates et al., 2006). Por último, permitimos efeitos de contágio de países vizinhos com dummies indicando se pelo menos um vizinho teve um pequeno conflito, conflito armado ou guerra durante um determinado ano.

\subsection{Estratégia Empírica}

Agora, desenvolvemos uma estrutura empírica que capta a natureza ordinal do conflito e inclui variáveis que têm efeitos dependentes do histórico.

Como típico em uma configuração ordenada, observamos um resultado de conflito que assume $J+1$ valores diferentes no país $i$ no momento t. Os resultados são ordenados por intensidade (paz, hostilidade, conflito armado e guerra civil) e são gerados por uma variável latente contínua com pontos de corte que serão estimados.

Nos modelos binários, a dependência de estado é a probabilidade de um evento acontecer quando o evento já aconteceu antes menos a probabi- 
lidade de o evento acontecer quando isso nunca aconteceu antes, constantes todos os outros fatores observados e não observados. Com resultados ordenados, não é mais tão simples assim. Precisamos explicar o fato de que existem várias maneiras de entrar em um determinado estado. Estimamos a dependência do estado como a diferença entre experimentar um estado particular se ele ocorreu antes e uma média ponderada das maneiras de entrar nesse estado quando ele não ocorreu antes.

Esperamos que a dependência do estado aumente com maiores intensidades de conflito. Quanto maior o nível de conflito, mais difícil se torna deixar estados violentos.

Usamos o fracionamento político em países doadores interagindo com a probabilidade de receber ajuda como fonte primária de variação exógena no nível doador-receptor. Dreher e Langlotz (2017) mostram que a fragmentação do governo interagindo com essa probabilidade é um instrumento forte para a ajuda bilateral. O fracionamento governamental é definida como a probabilidade de que quaisquer dois deputados escolhidos aleatoriamente dos partidos que formam o governo representem partidos diferentes (T. Beck et al., 2001). A motivação para este instrumento vem de três diferentes tipos de literatura. Em primeiro lugar, demonstrouse que o fracionamento governamental ou legislativa afeta positivamente as despesas do governo (Roubini e Sachs, 1989). Dentro de um governo de coalizão, o logrolling durante o processo orçamentário levará a gastos governamentais totais mais elevados. Segundo, gastos governamentais maiores estão associados com orçamentos maiores para a ajuda externa (Brech 
e Potrafke, 2014). Em terceiro lugar, os orçamentos de ajuda mais altos se traduzem em maiores desembolsos de ajuda (Dreher e Fuchs, 2011). A interação com a probabilidade de receber ajuda, em seguida, introduz variação entre os recipientes. Uma interação dessa probabilidade endógena com uma variável exógena é ela própria exógena, desde que incluamos efeitos fixos no país e no tempo (Nunn e Qian, 2014).

A maioria dos estudos que analisam os efeitos da fragmentação política nos gastos do governo se concentra nos sistemas parlamentares com representação proporcional. Isso ocorre porque os governos de coalizão são mais propensos a serem gerados por alguns sistemas do que por outros. As regras eleitorais, em particular as regras do first past the post (FPTP), definem se o governo pode ser fracionado ou se há um governo de partido único que negocia o processo orçamentário em algum tipo de processo de reconciliação com o órgão legislativo. Persson, Roland, Tabellini, et al. (2007) apresentam um modelo nessa direção, onde eleições majoritárias geralmente levam a um governo de partido único e menos gastos do que proporcionais. Assim, preferimos o fracionamento governamental sobre o fracionamento do legislativo como um instrumento nos sistemas parlamentares com representação proporcional.

Para os poucos doadores com sistemas de FPTP - Canadá, Reino Unido e EUA - utilizamos o fracionamento legislativo como fonte de variação exógena. Isso também está de acordo com Ahmed (2016), que mostra que um fracionamento mais alto na Câmara dos Deputados dos EUA leva ao aumento dos desembolsos da ajuda. 
Semelhante a (Nunn e Qian, 2014), essencialmente comparamos os efeitos da ajuda induzida por mudanças no fracionamento político em países receptores. De fato, a probabilidade é significativamente correlacionada com a quantidade de ajuda recebida. Em média, os países com maior probabilidade de receber ajuda também são aqueles a quem mais ajuda é enviada pelos doadores.

\subsection{Resultados}

\subsubsection{Estimação da Ajuda}

Para construir o instrumento, regredimos a ajuda recebida por cada recipiente de um doador em particular (como parcela do PIB receptor) em fracionamentos políticos, sua interação com a probabilidade de receber ajuda e efeitos fixos de país e tempo. Esses modelos são estimados com a fração de ajuda no PIB como a variável dependente.

A regressão é estimada em 4.166 relações bilaterais doador-receptor para as quais temos dados, produzindo um total de 129.348 observações. Esses resultados não pretendem ser interpretados por conta própria. Eles servem para "traduzir" a variação exógena nas características dos doadores em mudanças nos desembolsos da ajuda ao nível do receptor, dependendo de quão fortemente um receptor depende da ajuda de cada doador em particular.

Os coeficientes nos termos de interação são altamente significativos. 
Em ambos os casos, o aumento do fracionamento político leva a mais desembolsos de ajuda para quase toda a amostra. Curiosamente, sistemas parlamentares fracionados dão mais aos receptores regulares, enquanto sistemas majoritários divididos dão mais aos receptores irregulares. Agrupamos os erros padrão no nível do doador-receptor. A estatística F robusta dos termos de interação é de cerca de 10,83. Como essa é a principal fonte de variação exógena, ela pode ser comparada ao valor convencional de 10.

Agora nos voltamos para as estimativas de nível de país da relação do primeiro estágio. A Tabela 10 mostra três regressões de forma reduzida para a ajuda/PIB. A amostra é balanceada com $\mathrm{T}=35$ e $\mathrm{N}=125$. Os dados contêm países que enfrentam alguns dos maiores e mais antigos conflitos civis (por exemplo, Afeganistão, Iraque, Paquistão e muitos outros).

Duas coisas se destacam na Tabela 10. Primeiro, os coeficientes estimados nos instrumentos em todas as colunas são sempre ligeiramente superiores a um. Dependendo da especificação, um aumento de um ponto percentual na relação entre a ajuda prevista e o PIB leva a um aumento de cerca de 1,3 ponto percentual na ajuda real ao PIB. Adicionar outros controles move os coeficientes estimados para mais perto da unidade. Como esperado, isso sugere que os instrumentos capturam uma ajuda bastante ampla. Em segundo lugar, as estatísticas F sempre excedem o nível convencional de 10 por uma ordem de grandeza. Portanto, parece seguro concluir que as mudanças agregadas na ajuda induzida pelos resultados eleitorais nos países doadores interagiram com a probabilidade de receber 
Tabela 10: Primeiro Estágio

\begin{tabular}{|c|c|c|c|}
\hline & $\overline{(1)}$ & $(2)$ & (3) \\
\hline Ajuda/PIB Previsto & $\begin{array}{c}1.352^{* * *} \\
(0.088)\end{array}$ & $\begin{array}{c}1.234^{* * *} \\
(0.067)\end{array}$ & $\begin{array}{c}1.234^{* * *} \\
(0.068)\end{array}$ \\
\hline PIB per capita & & $\begin{array}{c}-5.089^{* * *} \\
(0.845)\end{array}$ & \\
\hline PIB & & & $\begin{array}{c}-5.114^{* * *} \\
(0.806)\end{array}$ \\
\hline População & & & $\begin{array}{c}6.084^{* * *} \\
(2.306)\end{array}$ \\
\hline Efeitos Fixos & Sim & Sim & Sim \\
\hline $\mathrm{N}$ & 4375 & 4375 & 4375 \\
\hline
\end{tabular}

ajuda para um instrumento de ajuda ao desenvolvimento.

Várias outras preocupações poderiam ser levantadas em relação à força e validade da estratégia de identificação. Governos e legislaturas fracionados poderiam estar dando mais ajuda a países que são politicamente mais próximos, mais abertos ao comércio ou que recebem muitos investimentos estrangeiros diretos. Qualquer correlação do instrumento com essas variáveis pode enfraquecê-lo e violar a restrição de exclusão em algumas circunstâncias. No entanto, seguindo Dreher e Langlotz (2017), observe que uma violação da restrição de exclusão requer não apenas que os desembolsos de ajuda induzidos pelo fracionamento variem em conjunto com outras variáveis e que essas variáveis determinem conflito, também requer que essas outras variáveis tenham efeito heterogêneo sobre recebedores regulares e irregulares. 


\subsubsection{Resultados}

São incluídos um conjunto de controles nas principais especificações, permitindo a heterogeneidade não observada para cada país (efeito fixo), efeitos de tempo não observados e nossa variável de interesse variando no tempo. Apresentamos dois conjuntos de estimativas para os resultados. A Tabela 11 mostra os resultados da regressão e a Tabela 12 mostra os efeitos parciais médios da ajuda nas diferentes transições.

Considerando os resultados da Tabela 11, na coluna (1), mostramos as estimativas sem controles adicionais, em seguida adicionamos o PIB per capita, e então permitimos que o PIB e a população tenham efeitos diferentes na última coluna. Os resultados são interessantes em alguns aspectos. Os coeficientes de ajuda ao PIB e suas interações com os estados atrasados são praticamente os mesmos em todas as três especificações. As regressões sugerem que o efeito positivo da ajuda ao conflito é mais forte se o país tiver um pequeno conflito no ano anterior e que o efeito não é estatisticamente diferente do nível de referência para maiores intensidades de conflito. Também encontramos evidências razoavelmente fortes da endogeneidade da ajuda. Os resíduos do primeiro estágio têm os sinais opostos e magnitudes similares aos coeficientes no nível básico. Isso sugere que encontraríamos um efeito zero de ajuda no conflito, se não corrigirmos a endogeneidade.

Para avaliar a magnitude dos efeitos implícitos, devemos nos voltar para efeitos parciais, em oposição aos coeficientes estimados. A Tabela 12 
Tabela 11: Segundo Estágio

\begin{tabular}{lccc}
\hline \hline & $(1)$ & $(2)$ & $(3)$ \\
& & & \\
\hline Ajuda/PIB Previsto & $0.0728^{*}$ & 0.0729 & 0.0721 \\
& $(0.0432)$ & $(0.0491)$ & $(0.0468)$ \\
Hostilidades (t-1) & $0.582^{* * *}$ & $0.578^{* * *}$ & $0.576^{* * *}$ \\
& $(0.0744)$ & $(0.0752)$ & $(0.0794)$ \\
Conflito Armado (t-1) & $2.110^{* * *}$ & $2.098^{* * *}$ & $2.107^{* * *}$ \\
& $(0.181)$ & $(0.185)$ & $(0.19)$ \\
Guerra Civil (t-1) & $3.429^{* * *}$ & $3.406^{* * *}$ & $3.424^{* * *}$ \\
& $(0.227)$ & $(0.230)$ & $(0.241)$ \\
Ajuda*Hostilidades & $0.022^{* * *}$ & $0.0209^{* *}$ & $0.212^{* *}$ \\
& $(0.007)$ & $(0.008)$ & $(0.008)$ \\
Ajuda*C. Armado & -0.008 & -0.01 & -0.01 \\
& $(0.0187)$ & $(0.0191)$ & $(0.0191)$ \\
Ajuda*Guerra Civil & -0.002 & -0.001 & -0.002 \\
& $(0.0240)$ & $(0.0252)$ & $(0.0248)$ \\
\hline PIB per capita & & 0.253 & \\
& & $(0.339)$ & \\
PIB & & & 0.289 \\
& & & $(0.310)$ \\
População & & & $(0.509)$ \\
\hline Efeitos Fixos & Sim & Sim & Sim \\
N & 4375 & 4375 & 4375 \\
\hline \hline
\end{tabular}

Erros-padrões robustos em parênteses

${ }^{*} p<0.1,{ }^{* *} p<0.05,{ }^{* * *} p<0.01$ 
relata estimativas para uma mudança de um ponto percentual na ajuda sobre as várias probabilidades de transição. Embora todas as estimativas acima da diagonal sejam positivas e as abaixo negativas, não encontramos evidências estatisticamente significativas em favor de um efeito da ajuda no conflito quando os países estão inteiramente em paz ou envolvidos em um conflito com mais de 25 mortes. A ajuda tem efeitos adversos significativos em ambientes voláteis que não são inteiramente pacíficos, mas também não (ainda) totalmente envolvidos em conflitos armados. Lá, mais ajuda torna a paz menos provável, mas a continuação de pequenos conflitos e uma transição para conflitos armados é mais provável. Um aumento de um ponto percentual na proporção da ajuda externa ao PIB leva a um aumento de cerca de 1,4 ponto percentual na probabilidade de transição de um pequeno conflito para um conflito armado. O mesmo aumento na ajuda também aumenta significativamente a probabilidade de permanecer em um pequeno conflito (em cerca de 1,4 ponto percentual) e torna a transição para a paz muito menos provável (cerca de $-2,9$ pontos percentuais)

Tabela 12: Efeito da Ajuda sobre a Probabilidade de Transição

\begin{tabular}{ccccc}
\hline \hline & \multicolumn{4}{c}{ Transição para: } \\
& Paz & Hostilidades & Conflito Armado & Guerra Civil \\
\hline Paz & 1.639 & 1.154 & 0.475 & 0.010 \\
Hostilidades & $-2.867^{*}$ & $1.439^{* *}$ & $1.358^{* *}$ & 0.070 \\
Conflito Armado & -1.379 & -0.539 & 1.333 & 0.585 \\
Guerra Civil & -0.401 & -0.970 & -0.618 & 1.989 \\
\hline \hline
\end{tabular}




\subsubsection{Probabilidades de Transição}

Com esses dados, podemos quantificar a persistência e a dependência do estado, ou seja, estudar como a ajuda ao desenvolvimento altera esses relacionamentos ao longo do tempo.

Tabela 13: Probabilidades de Transição

\begin{tabular}{ccccc}
\hline \hline & \multicolumn{4}{c}{ Transição para: } \\
& Paz & Hostilidades & Conflito Armado & Guerra Civil \\
\hline Paz & 79.95 & 16.34 & 3.65 & 0.04 \\
Hostilidades & 61.75 & 27.46 & 10.49 & 0.29 \\
Conflito Armado & 21.78 & 32.69 & 39.74 & 5.77 \\
Guerra Civil & 3.48 & 13.83 & 51.10 & 31.58 \\
\hline
\end{tabular}

A Tabela 13 mostra as probabilidades médias de transição em cada estado. A diagonal dessa matriz mostra as taxas de persistência previstas e os elementos fora da diagonal são as probabilidades de escalonamento e atenuação do conflito, respectivamente. Observe que definimos persistência e continuação em analogia, de modo que a persistência seja simplesmente a probabilidade estimada de permanecer em um determinado estado.

Encontramos forte evidência de dependência do estado em cada um dos quatro estados, mesmo após o controle da heterogeneidade observada e não observada. Dependência do estado em conflitos armados e guerra civil é moderadamente alta e muito semelhante. Para ambos os tipos de conflito, o simples fato de um país se encontrar em conflito implica que a probabilidade de permanecer em conflito aumenta cerca de 30 pontos percentuais. A comparação dessas estimativas com as probabilidades de 
persistência mostradas na diagonal é particularmente instrutiva. A dependência do Estado explica a maior parte da persistência nos conflitos armados e na guerra civil, mas muito menos em pequenos conflitos e paz.

\subsection{Conclusão}

Este artigo estuda os efeitos da ajuda ao desenvolvimento no conflito. Embora exista uma grande literatura sobre o assunto, ela tipicamente separa o início de um conflito de sua continuação e negligencia atos menores de violência.

Os resultados mostram que os efeitos da ajuda bilateral são heterogêneos em relação aos diferentes níveis de intensidade de conflito. Enquanto a ajuda aumenta a probabilidade de que um conflito se agrave de um nível baixo para um conflito armado, não encontramos nenhum efeito estatisticamente significativo da ajuda em países pacíficos. A ajuda também não afeta as probabilidades de transição quando um país experimenta um conflito armado ou uma guerra civil. Estes resultados sublinham a importância de separar situações verdadeiramente pacíficas de países expostos a pequenos conflitos. Se não levarmos em conta essa distinção, não conseguiríamos detectar um efeito de ajuda no conflito.

O trabalho ressalta que os doadores devem estar cientes das consequências não intencionais ao dar ajuda a países com conflitos prolongados. Isto pode ser de particular importância quando a luta para, mas os conflitos subjacentes não são totalmente resolvidos. 
Anexo 


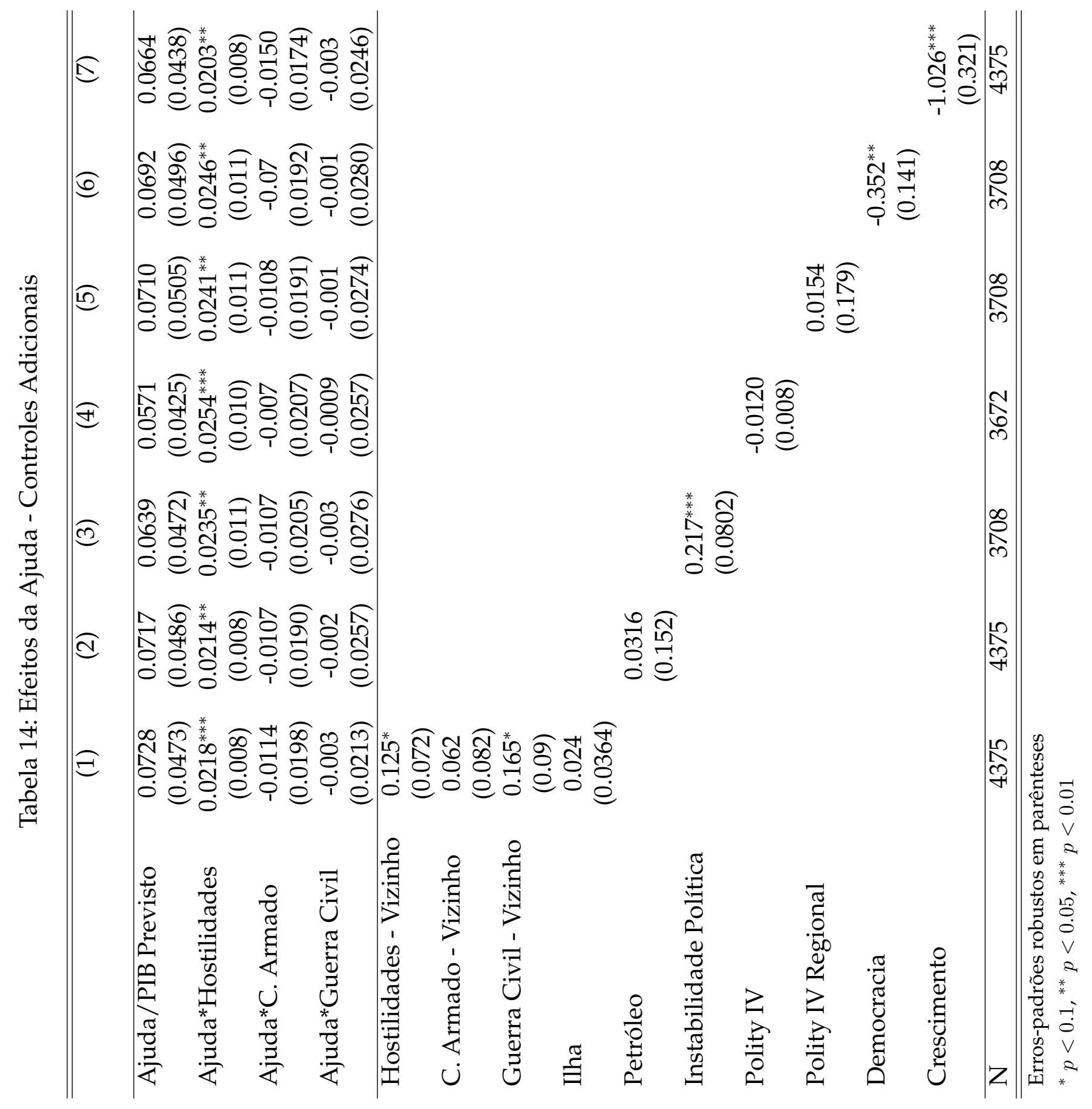




\section{Referências Bibliográficas}

Acemoglu, D., e Robinson, J. (2009). Economic origins of dictatorship and democracy. Cambridge University Press.

Acemoglu, D., e Wolitzky, A. (2014). Cycles of conflict: An economic model. American Economic Review, 104(4), 1350-67.

Ahmed, F. Z. (2016). Does foreign aid harm political rights? evidence from us aid. Quarterly Journal of Political Science, 11(2), 183-217.

Alesina, A., e Dollar, D. (2000). Who gives foreign aid to whom and why? Journal of economic growth, 5(1), 33-63.

Alvarez, M., Cheibub, J., Limongi, F., e Przeworski, A. (2000). Democracy and development: Political institutions and material well being in the world. New York: Cambridge University Press.

Ayittey, G. B. (2005). Africa unchained: The blueprint for africa's future. Palgrave Macmillan New York, NY.

Banful, A. B. (2011). Old problems in the new solutions? politically motivated allocation of program benefits and the ŞnewŤ fertilizer subsidies. World Development, 39(7), 1166-1176.

Banik, D. (2010). Poverty and elusive development. Universitetsforlaget.

Banks, A. S. (2015). Cross-national time-series data archive user's manual. Center for Social Analysis, State University of New York at Binghamton.

Bazzi, S., e Blattman, C. (2014). Economic shocks and conflict: Evidence from commodity prices. American Economic Journal: Macroeconomics, $6(4), 1-38$.

Beck, N., e Katz, J. N. (1995). What to do (and not to do) with time-series 
cross-section data. American political science review, 89(03), 634-647.

Beck, N., Katz, J. N., e Tucker, R. (1998). Taking time seriously: Time-seriescross-section analysis with a binary dependent variable. American Journal of Political Science, 1260-1288.

Beck, T., Clarke, G., Groff, A., Keefer, P., e Walsh, P. (2001). New tools in comparative political economy: The database of political institutions. the world bank economic review, 15(1), 165-176.

Becker, G. S. (1968). Crime and punishment: An economic approach. In The economic dimensions of crime (pp. 13-68). Springer.

Berman, N., e Couttenier, M. (2015). External shocks, internal shots: the geography of civil conflicts. Review of Economics and Statistics, 97(4), 758-776.

Besley, T., e Persson, T. (2011a). Fragile states and development policy. Journal of the European Economic Association, 9(3), 371-398.

Besley, T., e Persson, T. (2011b). The logic of political violence. The quarterly journal of economics, 126(3), 1411-1445.

Blattman, C., e Miguel, E. (2010). Civil war. Journal of Economic literature, $48(1), 3-57$.

Block, S. A. (2002). Political business cycles, democratization, and economic reform: the case of africa. Journal of Development economics, 67(1), 205-228.

Boone, P. (1994). The impact of foreign aid on savings and growth. London School of Economics and Political Science, Centre for Economic Performance.

Bräutigam, D. (2011). Aid Świth chinese characteristicsŠ: Chinese foreign 
aid and development finance meet the oecd-dac aid regime. Journal of international development, 23(5), 752-764.

Bräutigam, D. A., e Knack, S. (2004). Foreign aid, institutions, and governance in sub-saharan africa. Economic development and cultural change, $52(2), 255-285$.

Brech, V., e Potrafke, N. (2014). Donor ideology and types of foreign aid. Journal of Comparative Economics, 42(1), 61-75.

Briggs, R. C. (2012). Electrifying the base? aid and incumbent advantage in ghana. The Journal of Modern African Studies, 50(4), 603-624.

Briggs, R. C. (2014). Aiding and abetting: project aid and ethnic politics in kenya. World Development, 64, 194-205.

Burgess, R., Jedwab, R., Miguel, E., Morjaria, A., e Padr Miquel, G. (2015). The value of democracy: evidence from road building in kenya. American Economic Review, 105(6), 1817-51.

Burnside, A. C., e Dollar, D. (2004). Aid, policies, and growth: revisiting the evidence. World Bank Policy Research Working Paper(3251).

Casas, A. (2012). Strategic campaigning with vote and turnout buying: Theory and evidence.

Cheibub, J. A., Gandhi, J., e Vreeland, J. R. (2010). Democracy and dictatorship revisited. Public Choice, 143(1-2), 67-101.

Chenery, H. B., e Eckstein, P. (1970). Development alternatives for latin america. The Journal of Political Economy, 966-1006.

Clemens, M. A., Radelet, S., Bhavnani, R. R., e Bazzi, S. (2012). Counting chickens when they hatch: Timing and the effects of aid on growth. The Economic Journal, 122(561), 590-617. 
Collier, P., e Dollar, D. (2002). Aid allocation and poverty reduction. European Economic Review, 46(8), 1475-1500.

Collier, P., e Hoeffler, A. (2004). Greed and grievance in civil war. Oxford economic papers, 56(4), 563-595.

Collier, P., e Hoeffler, A. (2006, jan). Military expenditure in post-conflict societies. Economics of Governance, 7(1), 89-107. doi: 10.1007/s10101 $-004-0091-9$

Cox, G. W., e McCubbins, M. D. (1986). Electoral politics as a redistributive game. The Journal of Politics, 48(2), 370-389.

Crost, B., Felter, J., e Johnston, P. (2014). Aid under fire: Development projects and civil conflict. American Economic Review, 104(6), 183356.

Dal Bó, E., e Dal Bó, P. (2011). Workers, warriors, and criminals: social conflict in general equilibrium. Journal of the European Economic Association, 9(4), 646-677.

Dalgaard, C.-J., e Hansen, H. (2001). On aid, growth and good policies. Journal of development Studies, 37(6), 17-41.

De Ree, J., e Nillesen, E. (2009). Aiding violence or peace? the impact of foreign aid on the risk of civil conflict in sub-saharan africa. Journal of Development Economics, 88(2), 301-313.

Dixit, A., e Londregan, J. (1996). The determinants of success of special interests in redistributive politics. the Journal of Politics, 58(4), 11321155.

Doucouliagos, H., e Ulubalu, M. A. (2008). Democracy and economic growth: a meta-analysis. American Journal of Political Science, 52(1), 
$61-83$.

Dreher, A., e Fuchs, A. (2011). Rogue aid? the determinants of chinaŠs aid allocation.

Dreher, A., Fuchs, A., Hodler, R., Parks, B., Raschky, P., e Tierney, M. (2016). Aid on demand: African leaders and the geography of china's foreign assistance.

Dreher, A., e Langlotz, S. (2017). Aid and growth. new evidence using an excludable instrument.

Dreher, A., Nunnenkamp, P., e Thiele, R. (2011). Are ŚnewŠdonors different? comparing the allocation of bilateral aid between nondac and dac donor countries. World Development, 39(11), 1950-1968.

Dube, O., e Naidu, S. (2015). Bases, bullets, and ballots: The effect of us military aid on political conflict in colombia. The Journal of Politics, 77(1), 249-267.

Fearon, J. (2008). Economic development, insurgency, and civil war. Institutions and economic performance, 292, 328.

Fearon, J. D. (2005, aug). Primary commodity exports and civil war. Journal of Conflict Resolution, 49(4), 483-507. doi: 10.1177/0022002705277544

Fearon, J. D., e Laitin, D. D. (2003). Ethnicity, insurgency, and civil war. American political science review, 97(1), 75-90.

Franck, R., e Rainer, I. (2012, may). Does the leaders ethnicity matter? ethnic favoritism, education, and health in sub-saharan africa. American Political Science Review, 106(02), 294-325. doi: 10.1017/ s0003055412000172

Frankel, J. A., e Romer, D. H. (1999). Does trade cause growth? American 
economic review, 89(3), 379-399.

Gates, S., Hegre, H., Jones, M. P., e Strand, H. (2006). Institutional inconsistency and political instability: Polity duration, 1800-2000. American Journal of Political Science, 50(4), 893-908.

Gilbert, C. L., e Vines, D. (2006). The world bank: structure and policies (Vol. 3). Cambridge University Press.

Giles, J., e Murtazashvili, I. (2013). A control function approach to estimating dynamic probit models with endogenous regressorsa. Journal of Econometric Methods, 2(1), 69-87.

Gleditsch, N. P., Wallensteen, P., Eriksson, M., Sollenberg, M., e Strand, H. (2002). Armed conflict 1946-2001: A new dataset. Journal of peace research, 39(5), 615-637.

Goemans, H. E., Gleditsch, K. S., e Chiozza, G. (2009). Introducing archigos: A dataset of political leaders. Journal of Peace research, 46(2), $269-283$.

Green, D. P., Kim, S. Y., e Yoon, D. H. (2001). Dirty pool. International Organization, 55(02), 441-468.

Grossman, H. I. (1991). A general equilibrium model of insurrections. The American Economic Review, 912-921.

Hansen, H., e Tarp, F. (2000). Aid effectiveness disputed. Foreign Aid and Development: Lessons Learnt and Directions for the Future, 103-128.

Hansen, H., e Tarp, F. (2001). Aid and growth regressions. Journal of development Economics, 64(2), 547-570.

Hegre, H., e Sambanis, N. (2006). Sensitivity analysis of empirical results on civil war onset. Journal of conflict resolution, 50(4), 508-535. 
Henderson, J. V., Storeygard, A., e Weil, D. N. (2012). Measuring economic growth from outer space. American economic review, 102(2), 994-1028.

Hicken, A. (2011). Clientelism. Annual Review of Political Science, 14, 289310.

Hirshleifer, J. (1989). Conflict and rent-seeking success functions: Ratio vs. difference models of relative success. Public choice, 63(2), 101-112.

Hodler, R., e Raschky, P. A. (2014). Regional favoritism. The Quarterly Journal of Economics, 129(2), 995-1033.

Hudson, J., e Mosley, P. (2001). Aid policies and growth: In search of the holy grail. Journal of International development, 13(7), 1023-1038.

Jablonski, R. S. (2014). How aid targets votes: the impact of electoral incentives on foreign aid distribution. World Politics, 66(2), 293-330.

Kasara, K. (2007). Tax me if you can: Ethnic geography, democracy, and the taxation of agriculture in africa. American Political Science Review, 101(1), 159-172.

Kollman, K., Hicken, A., Caramani, D., e Backer, D. (2013). Constituencylevel elections archive (clea) university of michigan. Center for Political Studies [producer and distributor]. Date accessed.

Kramon, E., e Posner, D. N. (2013). Who benefits from distributive politics? how the outcome one studies affects the answer one gets. Perspectives on Politics, 11(2), 461-474.

Kuziemko, I., e Werker, E. (2006). How much is a seat on the security council worth? foreign aid and bribery at the united nations. Journal of political economy, 114(5), 905-930.

Kuznets, S. (1955). Economic growth and income inequality. The American 
economic review, 1-28.

Lensink, R., e White, H. (2001). Are there negative returns to aid? Journal of development Studies, 37(6), 42-65.

Levine, R., e Roodman, D. (2003). New data, new doubts: Revisiting 'aid, policies, and growth'. Center for Global Development, 11.

Licht, A. A. (2010). Coming into money: The impact of foreign aid on leader survival. Journal of Conflict Resolution, 54(1), 58-87.

Lindbeck, A., e Weibull, J. W. (1987). Balanced-budget redistribution as the outcome of political competition. Public choice, 52(3), 273-297.

Lindberg, S. I., e Morrison, M. K. (2008). Are african voters really ethnic or clientelistic? survey evidence from ghana. Political Science Quarterly, 123(1), 95-122.

Lu, S., e Ram, R. (2001). Foreign aid, government policies, and economic growth: Further evidence from cross-country panel data for 19701993. Economia Internazionale/International Economics, 54(1), 15-29.

Manning, R. (2006). Will Śemerging donorsŠ change the face of international co-operation? Development policy review, 24(4), 371-385.

Masaki, T. (2018). The political economy of aid allocation in africa: Evidence from zambia. African Studies Review, 61(1), 55-82.

McKinley, R. D., e Little, R. (1979). The us aid relationship: a test of the recipient need and the donor interest models. Political Studies, 27(2), $236-250$

Meredith, M. (2007). The fate of africa: A history of fifty years of independence. PublicAffairs.

Mesquita, B. B., e Smith, A. (2005). The logic of political survival. MIT press. 
Mesquita, B. B. d., e Smith, A. (2007). Foreign aid and policy concessions. Journal of Conflict Resolution, 51(2), 251-284.

Mesquita, B. B. d., e Smith, A. (2009). A political economy of aid. International Organization, 63(02), 309-340.

Mesquita, E. B. d. (2013, apr). Rebel tactics. Journal of Political Economy, 121(2), 323-357. doi: 10.1086/670137

Miguel, E., e Zaidi, F. (2008). Do politicians reward their supporters? regression discontinuity evidence from ghana. Working Paper.

Morgenthau, H. J. (1962). Politics in the twentieth century: The restoration of american politics (Vol. 3). University of Chicago Press.

Moser, C. (2008). Poverty reduction, patronage, or vote buying? the allocation of public goods and the 2001 election in madagascar. Economic Development and Cultural Change, 57(1), 137-162.

Mundial, B. (1992). Governance and development. In Governance and development. World Bank.

Mundial, B. (2014). World development indicators 2014.

Nordhaus, W. D. (1975). The political business cycle. The review of economic studies, 42(2), 169-190.

Nunn, N., e Qian, N. (2014). Us food aid and civil conflict. American Economic Review, 104(6), 1630-66.

Nunnenkamp, P., e Thiele, R. (2006). Targeting aid to the needy and deserving: nothing but promises? The World Economy, 29(9), 1177-1201.

Öhler, H., e Nunnenkamp, P. (2014). Needs-based targeting or favoritism? the regional allocation of multilateral aid within recipient countries. Kyklos, 67(3), 420-446. 
Persson, T., Roland, G., Tabellini, G., et al. (2007). Electoral rules and government spending in parliamentary democracies. Quarterly Journal of Political Science, 2(2), 155-188.

Persson, T., e Tabellini, G. (1999). The size and scope of government:: Comparative politics with rational politicians. European Economic Review, 43(4-6), 699-735.

Persson, T., Tabellini, G., e Trebbi, F. (2003). Electoral rules and corruption. journal of the European Economic Association, 1(4), 958-989.

Posner, D. N. (2007). Regime change and ethnic cleavages in africa. Comparative Political Studies, 40(11), 1302-1327.

Radelet, S. (2006). A primer on foreign aid. Center for Global Development working paper, 92.

Rajan, R. G., e Subramanian, A. (2008). Aid and growth: What does the cross-country evidence really show? The Review of economics and Statistics, 90(4), 643-665.

Rivers, D., e Vuong, Q. H. (1988, nov). Limited information estimators and exogeneity tests for simultaneous probit models. Journal of Econometrics, 39(3), 347-366. doi: 10.1016/0304-4076(88)90063-2

Robinson, J. A., e Verdier, T. (2013). The political economy of clientelism. The Scandinavian Journal of Economics, 115(2), 260-291.

Roodman, D. (2006). How to do xtabond2: An introduction to difference and system gmm in stata.

Rosenstein-Rodan, P. N. (1961). International aid for underdeveloped countries. The Review of Economics and Statistics, 107-138.

Roubini, N., e Sachs, J. D. (1989). Political and economic determinants 
of budget deficits in the industrial democracies. European Economic Review, 33(5), 903-933.

Sachs, J. D., Warner, A., Åslund, A., e Fischer, S. (1995). Economic reform and the process of global integration. Brookings papers on economic activity, 1-118.

Savun, B., e Tirone, D. C. (2011). Foreign aid, democratization, and civil conflict: how does democracy aid affect civil conflict? American Journal of Political Science, 55(2), 233-246.

Shi, M., e Svensson, J. (2006). Political budget cycles: Do they differ across countries and why? Journal of public economics, 90(8-9), 1367-1389.

Stokes, S. C. (2005). Perverse accountability: A formal model of machine politics with evidence from argentina. American Political Science Review, 99(3), 315-325.

Tierney, M. J., Nielson, D. L., Hawkins, D. G., Roberts, J. T., Findley, M. G., Powers, R. M., ... Hicks, R. L. (2011). More dollars than sense: refining our knowledge of development finance using aiddata. World Development, 39(11), 1891-1906.

Tull, D. M. (2006). China's engagement in africa: scope, significance and consequences. The Journal of Modern African Studies, 44(3), 459-479.

Van der Walle, N. (2001). African economies and the politics of permanent crisis. Cambridge: Cambridge United Press.

Vogt, M., Bormann, N.-C., Rüegger, S., Cederman, L.-E., Hunziker, P., e Girardin, L. (2015). Integrating data on ethnicity, geography, and conflict: The ethnic power relations data set family. Journal of Conflict Resolution, 59(7), 1327-1342. 
Weghorst, K. R., e Lindberg, S. I. (2013). What drives the swing voter in africa? American Journal of Political Science, 57(3), 717-734.

Weingrod, A. (1968). Patrons, patronage, and political parties. Comparative studies in Society and History, 10(4), 377-400.

Weinstein, L. (2011). The politics of government expenditures in tanzania, 1999-2007. African Studies Review, 54(1), 33-57.

White, H. (1992). The macroeconomic impact of development aid: a critical survey. The Journal of Development Studies, 28(2), 163-240.

Winters, M. S. (2010, jun). Choosing to target: What types of countries get different types of world bank projects. World Politics, 62(03), 422-458. doi: $10.1017 / \mathrm{s} 0043887110000092$

Wintrobe, R. (1990). The tinpot and the totalitarian: An economic theory of dictatorship. American Political Science Review, 84(03), 849-872.

Woods, N. (2008). Whose aid? whose influence? china, emerging donors and the silent revolution in development assistance. International Affairs, 84(6), 1205-1221.

Wooldridge, J. M. (2005). Simple solutions to the initial conditions problem in dynamic, nonlinear panel data models with unobserved heterogeneity. Journal of applied econometrics, 20(1), 39-54.

Wright, J., e Winters, M. (2010). The politics of effective foreign aid. Annual Review of Political Science, 13, 61-80. 